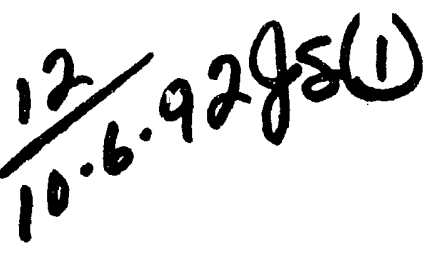

\title{
Technology Status Report: In Situ Vitrification Applied to Buried Wastes
}

L. E. Thompson

S. O. Bates

J. E. Hansen

September 1992

Prepared for the U.S. Department of Energy Office of Technology Development Contract DE-AC06-76RLO 1830

Pacific Northwest Laboratory Operated for the U.S. Department of Energy by Battelle Memorial Institute 


\title{
DISCLAIMER
}

This report was prepared as an account of work sponsored by an agency of the United States Government. Neither the United States Government nor any agency thereof, nor Battelle Memorial institute, nor any of their employees, makes any warranty, expressed or implied, or assumes any legal liability or responsibility for the accuracy, completeness, or usefulness of any information, apparatus, product, or process disclosed, or represents that its use would not infringe privately owned rights. Reference herein to any specific commercial product, process, or service by trade name, trademark, manufacturer, or otherwise does not necessarily constitute or imply its endorsement, recommendation, or favoring by the United States Government or any agency thereof, or Battelle Memorial Institute. The views and opinions of authors expressed herein do not necessarily state or reflect those of the United States Government or any agency thereof.

\author{
PACIFIC NORTHWEST LABORATORY \\ operated by \\ BATTELLE MEMORIAL INSTITUTE \\ for the \\ UNITED STATES DEPARTMENT OF ENERGY \\ under Contract DE-AC06-76RLO 1830
}

Printed in the United States of America

Available to DOE and DOE contractors from the

Office of Scientific and Technical Information, P.O. Box 62, Oak Ridge, IN 37831; prices available from (615) 576-8401. FTS 626-8401.

Available to the public from the National Technical information Service, U.5. Department of Commerce, 5285 Port Royal Rd., Springfield, VA 22161. 
TECHNOLOGY STATUS REPORT:

IN SITU VITRIFICATION APPLIED

TO BURIED WASTES
L. E. Thompsgn
S. 0. Bates
J. E. Hansen (b)

September 1992

Prepared for

the Office of Technology Development, U.S. Department of Energy, Washington, D.C., under Contract DE-ACO6-76RLO 1830

Pacific Morthwest Laboratory

Richland, Washington 99352
(a) EG\&G-Idaho, Inc. Idaho Falls, Idaho
(b) Geosafe Corporation Richland, Washington 


\section{SUMMARY}

This documient is a technical status report on In Situ Vitrification (ISV) as applied to buried waste; the report takes both technical and institutional concerns into perspective.

Historically, the major focus of ISV development efforts has been on applying the technology to remediate contaminated soils, but the U.S. Department of Energy's (DOE's) Office of Technology Development (OTD) has recently funded research into the use of ISV technology to remediate buried waste and underground tanks as well. Since 1988, a c-operative development program between Pacific Northwest Laboratory (PNL) and Idaho National Engineering Laboratory (INEL) has been the vehicle for the development of this ISV application.

The ISV process involves electrically melting such contaminated solid media as soil, sediment, sludge, and mill tailings. The resultant product is a high-quality glass-and-crystalline waste form that possesses high resistance to corrosion and leaching and is capable of long-term environmental exposure without significant degradation. The process also significantly reduces the volume of the treated solid media due to the removal of pore spaces in the soil. (Twenty to $45 \%$ volume reduction for most soils, and up to $75 \%$ for buried wastes, has been demonstrated to date.)

Although there are substantial issues that still require resolution, ISV offers remarkable advantages - technically, institutionally, and financially over other technologies for treating buried waste. Among those advantages are the following:

- In situ treatment avoids the need for excavation, which is typically very costly for buried-waste sites and poses an undesirable risk of contaminant release to the environment and the operational staff.

- The ability to process mixtures of hazardous, radioactive, and mixed waste avoids the need to separate/segregate and use multiple treatment technologies for buried wastes after excavation (very costly and high-risk alternatives). 
Vitrification provides tremendous volume reduction of buried waste and the surrounding soil. (A 75\% reduction has been demonstrated to date.)

- Vitrification provides unequalled immobilization benefits for hazardous and radioactive materials.

- The superior benefits of vitrification are attainable at significantly lower cost than with alternative technologies. In fact, developing ISV is 4 to 8 times less costly than the anticipated costs for developing other treatment technologies and, considering total life-cycle costs, use of ISV is 5 to 10 times less expensive than any other alternative.

Key remaining technical issues for this ISV application are detailed by Stoots (1991) and Nickelson (1992). Key issues, outlined in Section 5.0 of this report, include the following:

- sealed containers/containment - The ability must be developed to prevent and/or control transient gas releases that result from ISV processing of sealed containers, specifically drums.

- contiguous melts/residual wastes - The ability must be developed to control melt shape and depth in a buried-waste environment, to ensure the formation of contiguous melts, and to minimize residual unprocessed waste.

- contaminant migration/underground fires - An improved understanding of the potential for contaminant migration into surrounding soils and the potential for creating underground fires must be established.

- product quality - The long-term stability and acceptability of the ISV Product, as well as potential metal phases formed because of the high metal content of the buried waste, must be demonstrated.

- criticality - The ability of the ISV process to avoid the concentration of fissile materials, and the resultant potential for a criticality, must be conclusively established.

Although significant progress on these and other issues has been achieved to date, further work is necessary to develop the fundamental understanding of mechanisms underlying each issue.

This report, in part, describes the significant technical accomplishments achieved thus far during the development of ISV for buried-waste applications. These accomplishments are many, and they range from establishing an 
improved understanding of the ISV waste form to providing greater knowledge of the process behavior during vitrification. The improved understanding of the process has led to the development of relatively simple engineering solutions, such as the electrode-feed system, pressurized electrode seals, and a waterspray suppression-system, that enhance containment of the off-gases. These types of advances improve the safety and reliability of the ISV process. Based on the progress to date, it is apparent that remaining technical issues can indeed be resolved. 


\section{LIST OF ACRONYMS}

ARARs

BWID

BWP

CERCLA

DOD

DOE

DOE-ID

DT\&E/ER

EG\&G-ID

EPA

ER

ERP

FS

FY

INEL

ISV

NPL

OAT

ORNL

OTD

O\&M

PNL

PRP applicable or relevant and appropriate requirements

Buried Waste Integrated Demonstration

Buried Waste Program

Comprehensive Environmental Response, Compensation, and Liability Act

U.S. Department of Defense

U.S. Department of Energy

Department of Energy, Idaho Field Office

Demonstration, Testing, and Evaluation/Environmental Restoration

EG\&G Idaho, Incorporated

U.S. Environmental Protection Agency

Office of Environmental Restoration, DOE

Environmental Protection Program

feasibility study

fiscal year

Idaho National Engineering Laboratory

in situ vitrification

National Priority List

operational acceptance test

Oak Ridge National Laboratory

Office of Technical Development

operation and maintenance

Pacific Northwest Laboratory

principal responsible party 
research and development

RA

remedial action

RCRA

Resource Conservation and Recovery Act

RD

remedial design

RFP

Rocky Flats Plant

RI/FS

remedial investigation/feasibility study

ROD

record of decision

ROM

rough order of magnitude

RWMC

Radioactive Waste Management Complex

SARA

Superfund Amendments and Reauthorization Act of 1986

SDA

subsurface disposal area

TCLP

toxicity characteristic leach procedure

TRU

transuranic element

TSCA

Toxic Substances Control Act

VOC

volatile organic compound 


\section{CONTENTS}

SUMMARY .........................

LIST OF ACRONYMS ...................... . vii

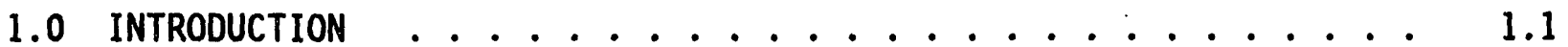

2.0 STATUS OF THE TECHNOLOGY ................ 2.1

2.1 SUMMARY PROCESS DESCRIPTION ............. 2.1

2.2 TYPES OF POTENTIAL APPLICATIONS .......... 2.2

2.3 APPLICATION STATUS . . . . . . . . . . . 2.3

2.4 ACCEPTANCE OF ISV TECHNOLOGY ............. 2.4

3.0 SIGNIFICANCE OF ISV TO DOE'S BURIED-WASTE REMEDIATION NEEDS . . . 3.1

3.1 BURIED-WASTE APPLICATION FOR DOE . . . . . . . . . 3.1

3.2 ADVANTAGES OFFERED TO DOE BY USE OF ISV . . . . . . 3.2

3.2.1 Baseline for Technology Development . . . . . . 3.2

3.2.2 Expected ISV Performance . . . . . . . . . . 3.3

3.2.3 Comparison of ISV in Meeting CERCLA Criteria . . . 3.3

3.2.4 Summary of Benefits to DOE . . . . . . . . . 3.7

4.0 TECHNOLOGY DEVELOPMENT/DEMONSTRATION NEEDS

AND RECOMMENDATIONS . . . . . . . . . . . . . . . 4.1

4.1 BURIED-WASTE TECHNICAL APPLICATION CRITERIA . . . . . 4.1

4.2 TECHNICAL RESEARCH, DEVELOPMENT, AN'D

DEMONSTRATION NEEDS $\ldots . . . . .4 .1$

5.0 TECHNOLOGY INSTITUTIONAL NEEDS AND RECOMMENDATIONS $\ldots \ldots$

5.1 EPA BURIED-WASTE INSTITUTIONAL APPLICATION CRITERIA $\ldots . . \quad 5.1$

5.2 DOE INSTITUTIONAL OBJECTIVES ............. 5.1

5.3 INSTITUTIONAL STATE OF THE TECHNOLOGY . . . . . . . . 5.1

5.3.1 EPA and State Regulatory Acceptance ........ 5.1 
5.j.2 Public Acceptance ............. . . 5.2

5.4 TECHNOLOGY TRANSFER ................ 5.3

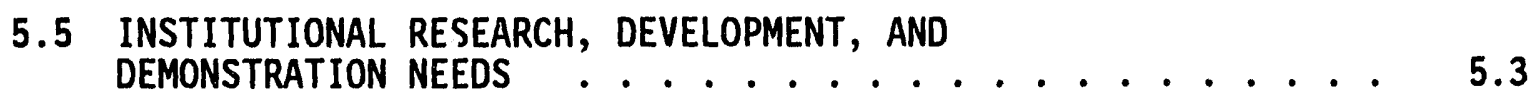

0.0 PROGRAMMATIC REQUIREMENTS TO SATISFY NEEDS . . . . . . . . . . 6.1

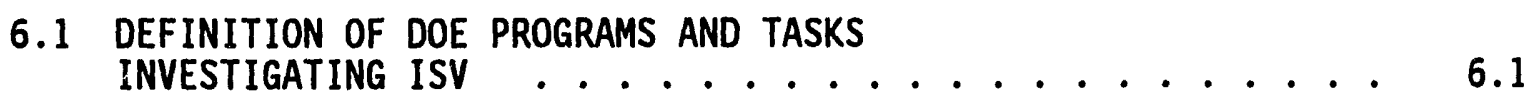

6.2 PROGRAMMATIC ISSUES AND PROGRESS ............ 6.2

6.3 PROGRAM BUDGET PROJECTIONS .............. 6.2

6.4 PROBABILITY OF PROGRAM SUCCESS ............ 6.3

7.0 RECENT ADVANCES IN ISV TECHNOLOGY . . . . . . . . . . . . . 7.1

7.1 ELECTRODE-FEEDING SYSTEM . . . . . . . . . . . 7.1

7.2 WATER-SPRAY SUPPRESSION-SYSTEM . . . . . . . . . . 7.4

7.3 EleCTRODE SEALS .................. 7.6

8.0 ISV'S CURRENT OPERATIONAL CAPABILITIES . . . . . . . . . . 8.1

8.1 SOIL TYPES ........................... 8.1

8.2 SOIL MOISTURE .................. 8.2

8.3 SOIL COMPOSITION .................... 8.2

8.4 DEPTH OF CONTAMINATION ............... 8.2

8.5 RADIONUCLIDES .................. 8.3

8.6 HAZARDOUS INORGANIC CHEMICALS ............ 8.3

8.7 HAZARDOUS ORGANIC CHEMICALS ............... 8.3

8.8 SCRAP METAlS .................... 8.4

8.9 DEBRIS AND RUBBLE ..................... 8.4

8.10 BURIED COMBUSTIBLES ................... 8.4

8.11 SEALED CONTAINERS ................... 8.5

8.12 VOID VOLUMES .................. 8.5 
9.0 REFERENCES ...................... 9.1

APPENDIX - KEY TECHNICAL ACCOMPLISHMENTS .............. A.1 
2.1 ISV Process Sequence ................. 2.2

3.1 ISV Technical Issues Relative to CERCLA Criteria . . . . . . 3.5

4.1 Generic Capabilities Required to Implement the ISV Technology Relative to the Superfund Model . . . . . . . . 4.2

7.1 Engineering-Scale Electrode-Feeding Mechanism . . . . . . . 7.2

7.2 Water-Spray Suppression-System Trials . . . . . . . . . . 7.5

7.3 Diagram of the Pressurized Electrode Seal . . . . . . . . . 7.7

\section{TABLE}

3.1 ROM Cost Comparison of In Situ and Ex Situ Treatment Options .............. 3.8 


\subsection{INTRODUCTION}

This document is a technical status report on In Situ Vitrification (ISV) as applied to buried-waste; the report takes both technical and institutional concerns into perspective. First, it presents a brief description of the ISV technology and its potential significance to the U.S. Department of Energy's (DOE's) buried-waste applications. Second, in order to define what needs remain to be satisfied by DOE's Office of Technology Development (OTD) program, the status of the technology is related to the technical and institutional requirements pertinent to buried-waste applications. Once various technical and institutional issues are largely resolved and the technology is at the completion of the research and development (R\&D) phase, a final technical status report should document the suitability of the technology to move fully to a Demonstration, Testing, and Evaluation/Environmental Restoration (DT\&E/ER) phase.

The current development focus for the ISV Integrated Program (ISV-IP) is contaminated soils. The primary objective of the ISV-IP is to resolve remaining issues associated with contaminated-soils applications. These remaining issues are currently preventing the broad deployment of the ISV technology on contaminated-soils sites. Technical issues associated with advanced applications, such as use on buried wastes and underground storage tanks, are not being pursued at this time except where issues associated with these advanced applications are common to contaminated-soils applications. At a later date, once the issues associated with contamirated soils are resolved and the ISV technology is deployed for contaminated-soils applications, development of the buried-waste application will be re-initiated if warranied.

The ISV technology has been under development since 1980 at Pacific Northwest Laboratory (PNL) ${ }^{\text {(a) }}$ (Buelt et al. 1987; Oma et a1. 1989). Initial effort was directed to contaminated-soils applications. The technology is now considered ready for 1 imited deployment for contaminated-soils applications,

(a) Pacific Northwest Laboratory is operated for the U.S. Department of Energy by Battelle Meworial Institute under Contract DE-ACO6-76RLO 1830.

\section{1}


and it has been transferred to a licensee, Geosafe Corporation, for commercial applications.

More recently, OTD has funded investigation and development of ISV for potential buried-waste and underground-tank remediation. Development for buried-waste applications was initiated in 1988 with a collaborative effort between PNL and EG\&G Idaho, Incorporated (EG\&G-ID) (Oma et a1. 1989). A summary description of the technical progress achieved to date for buriedwaste applications is given in the appendix. Currentiy, the tecinology for buried-waste applications is being developed through the Buried Waste Integrated Demonstration (BWID) and the ISV Integrated Program for DOE. This technology status report is limited to discussion of the buried-waste applications, primarily as the technology is being developed for application to the transuranic element (TRU)-contaminated pits and trenches at the Subsurface Disposal Area (SDA) at the Idaho National Engineering Laboratory (INEL).

The ISV technology is significantly less costly (4 to 8 times) than the development costs anticipated for other treatment alternatives and, considering total life-cycle costs, is 5 to 10 times less costly than other alternatives (Mayberry et al. 1991). Significant technical progress, including closure of several technical issues, has been achieved since development for buried-waste applications was initiated in 1988. Advances in equipment design and process knowledge regarding the behavior of the ISV process indicate that many technical issues investigated to date have been, or can be, satisfactorily addressed. Institutionally, public and regulatory acceptance is generally positive. Due to the relatively low cost, and the safety and environmental benefits of ISV, the technology should be vigorousiy pursued for buried-waste applications. 


\subsection{STRTUS OF THE TECHNOLOGY}

\subsection{SUMMARY PROCESS DESCRIPTION}

The ISV process involves the electric melting of contaminated solid media (such as soil, sediment, sludge, and mill tailings). The process is very effective in destroying, removing, and/or immobilizing hazardous chemicals, radioactive materials, and mixed contaminants. The process is performed in situ or in a prepared location where the contaminated media may be staged for treatment. The ISV process produces a high-quality glass-andcrystalline waste form that possesses high resistance to corrosion and leaching and is capable of long-term environmental exposure without significant degradation. The melting process also results in a significant volume reduction (20 to $45 \%$ for most soils and up to $75 \%$ for buried waste).

Figure 2.1 illustrates the stages of ISV processing. The melting process is accomplished through the conduction of electricity between an array of electrodes. A starter path of graphite and glass frit is placed between the electrodes to allow initiation of the process in typically non-conductive soil. Once the soil surface becomes molten, it becomes electrically conductive. Joule heating occurs within the molten soil as electricity flows through it, resulting in molten soil temperatures ranging from 1600 to $2000^{\circ} \mathrm{C}$. Heat is conducted from the melt into the adjacent soil, causing growth of the melt in both the downward and outward directions. Compiared with stationary electrodes, the use of electrode feeding provides significantly more control over the melt's shape.

The ISV equipment technology has been developed through bench-, engineering-, pilot-, and large-scale applications. The large-scale equipment system is capable of processing up to 1,000 tons of soil in a single melt at the rate of 4 to 6 tons $/ \mathrm{h}$. It employs 1) a 3,750 kVa multiple-tap transformer supplying electrical power to the electrodes; 2) an off-gas collection hood and an electrode-feed system; 3) an off-gas treatment system employing quenching, scrubbing, dewatering, filtering, and adsorption-unit processes; 4) a distributed microprocessor control system; and 5) an emergency/backup off-gas treatment system. 


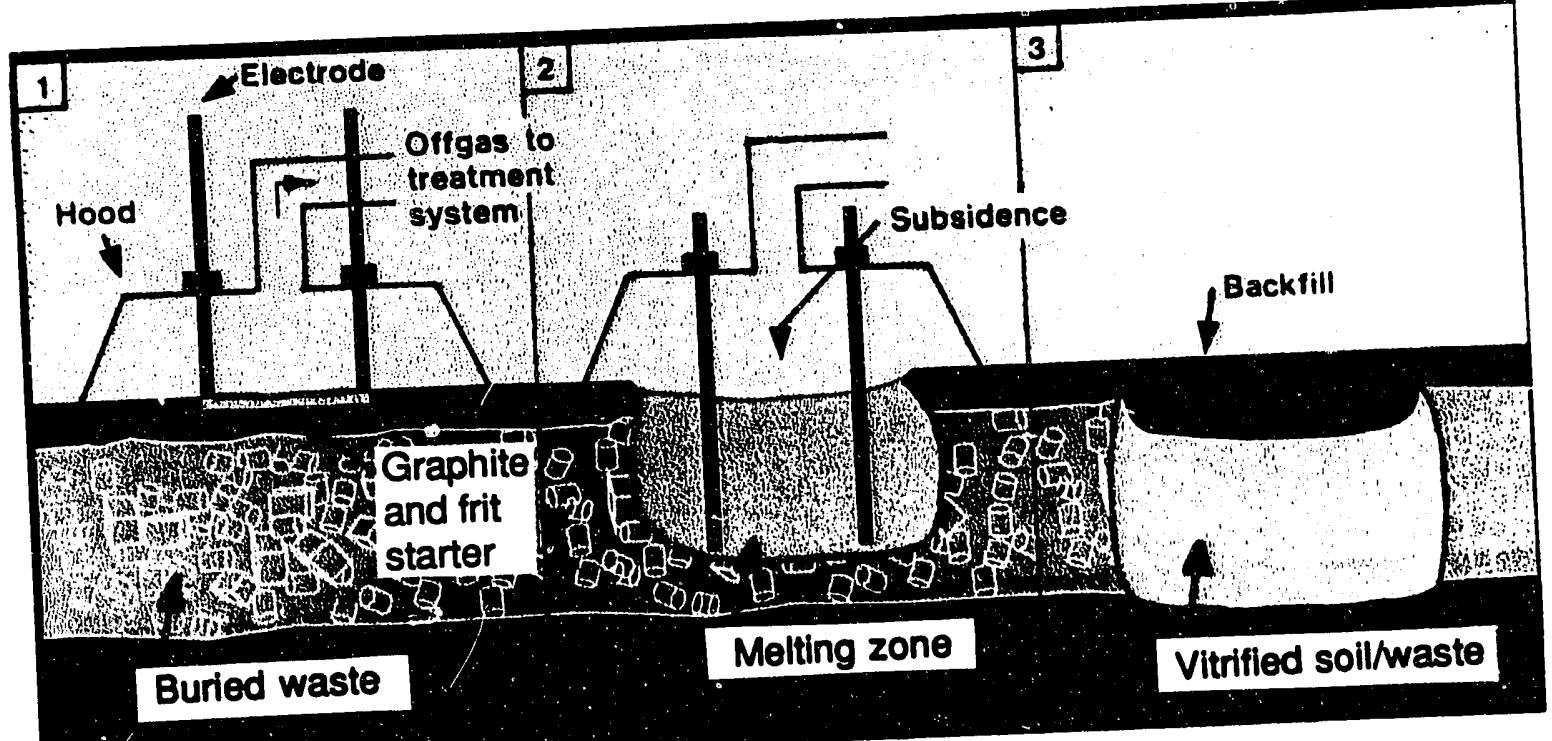

FIGURE 2.1. ISV Process Sequence

More than 150 individual tests of the ISV technology at various scales have evaluated the efficacy of the technology to treat a broad range of conicaminants and solid media types. The technology has been shown effective for destroying organic contaminants by pyrolysis. It has also been shown effective in the removal and/or immobilization of heavy metal contaminants or radionuclides within the vitrified residual product (Buelt et al. 1937).

The costs of applying ISV are very site-specific. For contaminated soil sites, Geosafe Corporation has estimated several non-radioactive site remediations to cost in the range of $\$ 350$ to $\$ 450 /$ ton, plus fixed costs of $\$ 150,000$ to $\$ 250,000$ combined for equipment mobilization and demobilization. A systems study conducted by INEL indicates that ISV costs are several times less than those of other, ex-situ, treatment alternatives, even when employed with a retrieval strategy (Mayberry et al. 1991).

\subsection{TYPES OF POTENTIAL APPLICATIONS}

Potential ISV applications may be categorized according to the type, condition, and location of the waste as indicated below: 
- type of waste

- hazardous chemical - organic

- hazardous chemical - inorganic

- radioactive

- mixtures of the above three types

- location of waste

- contaminated soil

- buried waste

- underground tanks or structures.

ISV may be applied to the waste where it is found (in situ) or where it has been staged for treatment.

\subsection{APPLICATION STATUS}

Buried-waste applications are unique because they involve containerized and non-containerized wastes that typically have been disposed of in a landfill. In 1990, field tests of the ISV technology on staged buried waste demonstrated the viability of this application (Callow et al. 1991). Detailed information regarding these field tests is contained in the Appendix. The buried waste may represent all combinations of hazardous, radioactive, mixed, and/or transuranic-contaminated wastes. Placement of the containers during disposal may have been random, or they may have been precisely stacked. The buried-waste containers may lack integrity due to damage incurred during placement or corrosion after burial. Buried-waste applications are also unique in that they typically represent much larger void:soil and waste:soil ratios than those involved in contaminated-soil applications. This situation may pose significantly higher vapor/gas volume generation, and may result in significantly different residual-product chemistry. Additionally, the presence of gas- or vapor-generating materials inside sealed containers is expected to result in transient surges of off-gas to the containment hood.

The ISV technology offers the following primary advantages compared with other technologies for treating buried waste:

- In situ treatment avoids the need for excavation and interim storage, which is typically very costly for buried-waste sites and poses an undesirable risk of contaminant release to the environment and the operational staff. 
- The ability to process mixtures of hazardous, radioactive, and mixed waste avoids the need to separate/segregate and use multiple treatment technologies for buried wastes after excavation (very costly and high-risk alternatives).

- Vitrification provides tremendous volume reduction of buried waste and the surrounding soil. (A 75\% reduction has been demonstrated to date; greater degrees of volume reduction are possible depending on soil-to-waste ratios.)

- Vitrification provides unequalled immobilization benefits for hazardous and radioactive materials.

- The superior benefits of vitrification are attainable at significantly lower cost than with alternative technologies.

\subsection{ACCEPTANCE OF ISV TECHNOLOGY}

The use of ISV for contaminated-soil applications has attained significant regulatory and public acceptance in the non-DOE marketplace. Regulatory acceptance has been primarily based on the technology's ability to satisfy the nine Comprehensive Environmental Response, Compensation, and Liability Act (CERCLA) evaluation criteria for comparing alternative technologies. (Similar criteria established by the Superfund Amendments and Reauthorization Act [SARA] of 1986 are applicable to commercial applications under the provisions of the Resource Conservation and Recovery Act [RCRA].) As noted above, ISV offers significant advantages for sices where there is a strong desire to avoid excavation and/or where multiple technologies would otherwise be required for remediation. The reasons for public acceptance, while difficult to define, appear to be related to the in situ nature of the ISV process and the quality of the ISV residual product.

The regulatory and public acceptance of the commercial offering of ISV technology is illustrated by its selection as a preferred remedy at ten private, EPA-Superfund, and U.S. Department of Defense (DOD) sites within the United States. All of these sites are considered to be contaminated-soil sites. None of these sites has undergone ISV remediation, although two are now ready for on-site vitrification operations, pending resolution of issues 
identified during Geosafe's equipment operational acceptance test. (a) The other sites are at various stages of the overall remediation process (e.g., regulator/principal responsible party (PRP) negotiations, treatability/pilot testing, remedial design).

Regulatory and public acceptance issues have not been addressed for buried-waste sites because the technology has not yet been made available for remediation of such sites. However, public and regulatory acceptance of the technology for use at buried-waste sites should compare favorably to its high acceptance for use on contaminated-soil for three primary reasons:

1) There are fewer alternatives for treating buried-waste than there are for contaminated soils.

2) Cost is a major factor in the selection of preferred remedies.

3) The risks associated with excavation of buried wastes are greater than for contaminated soils.

of course, both regulatory and public acceptance will require a demonstrated capability of the ISV technology to safely process buried wastes.

(a) Geosafe Corporation's prototype fabric off-gas containment hood was extensively damaged during the second of two equipment operational tests in March of 1991. The test involved several advanced features not previously tested on a large scale, including the presence of concrete walls on three sides of the melt, 20 sealed $55-\mathrm{gal}(208.2-\mathrm{L})$ drums filled with water-saturated soil, and operations at a high power level with stationary electrodes, which resulted in an unusual, undesirable melt shape. The off-gas containment hood damage was caused by a large mass of molten glass from the vitrification zone. An investigation team concluded that the primary cause of the glass displacement was likely a rapid release of water vapor from one or more sealed drums, resulting in an increased pressure in the soil under the melt, which in turn resulted in the formation of unusually large bubbles. 


\subsection{SIGNIFICANCE OF ISV TO DOE'S BURIED-WASTE REMEDIATION NEEDS}

\subsection{BURIED-WASTE APPLICATION FOR DOE}

ISV application to buried waste to date has been primarily focused on evaluating the ISV technology for use in remediation of the buried-waste site at the SDA at INEL. Similar situations involving buried waste contaminated with plutonium, mixed fission and activation products, and/or hazardous substances exist at numerous other DOE sites, including Hanford, Oak Ridge National Laboratory (ORNL), Rocky Flats, Sandia, and the Savannah River Plant. Sites involving buried waste contaminated with hazardous and/or radioactive substances exist at many of the EPA Superfund sites. Examples include the Ionia City, Michigan, landfill site and the Weldon Springs, Missouri, site. The evaluation and demonstration of this technology at the INEL will ultimately benefit other DOE, DOD, and commercial buried-waste sites as technical issues are resolved.

In 1952, the Radioactive Waste Management Complex (RWMC) was established at INEL. The RWMC is located on approximataly 144 acres in the southwestern corner of the INEL site. The RWMC was established as a controlled area for the burial of solid, low-level, TRU wastes generated by INEL operations. From 1954 to 1970, TRU waste was accepted from the Rocky Flats Plant (RFP) as well as from other DOE sites.

The buried-waste site occupies approximately $0.178 \mathrm{~km}^{2}$ (44 acres) of the SDA and consists of buried industrial solid wastes, primarily from the Rocky Flats Plant and the INEL. Approximately $118,000 \mathrm{~m}^{3}\left(4.2 \mathrm{million} \mathrm{ft}^{3}\right)$ of mixed hazardous and rudioactive waste is buried at the SDA. The wastes are principally contaminated with isotopes of plutonium, mixed fission products, mixed activation products, and hazardous substances. The waste material is located approximately $180 \mathrm{~m}(600 \mathrm{ft})$ above the Snake River Plain Aquifer, the largest underground aquifer in Idaho and a major source of water for human consumption, irrigation, and other agricultural uses in eastern Idaho.

Current concerns over the human health and environmental effects of the wastes disposed at the SDA have ariseir because various contaminants, notably solvents, were found in ground water underlying the site. These contaminants 
have been detected migrating away from the INEL site in the Snake River Plain Aquifer. In addition, organic contaminants and radionuclides have been detected in sedimentary interbeds and perched ground water beneath the SDA, indicating migration away from the disposal area. As a result of these discoveries, the SDA was included on the National Priority List (NPL) by the EPA as a waste site posing a long-term threat to human health and the environment under CERCLA. This listing led to the RI/FS currently being planned for the SDA.

Several factors complicate any remedial action:

- the toxicity of the principal contaminant (plutonium)

- the heterogeneous nature of the buried-waste matrix

- the questionable integrity of the various buried-waste packages

- the variety of waste forms

- the random nature of the original disposal practices.

In 1987, the Buried Waste Program (BWP), renamed the Environmental Restoration Program (ERP) in 1989, was established within EG\&G-ID. The ERP is conducting a CERCLA remedial investigation/feasibility study (RI/FS) for the DOE-Idaho Field Office (DOE-ID). As part of the RI/FS, an ISV scoping study on the treatability of the SDA's mixed low-level and TRU waste was performed for applicability to remediation of the waste at the SDA.

\subsection{ADVANTAGES OFFERED TO DOE BY USE OF ISV}

\subsubsection{Baseline Technology for Development}

There is currently no baseline technology established for buried-waste applications; however, retrieval followed by physical and chemical separation is considered a strong candidate at INEL. Currently identified alternatives to the use of ISV technology for the remediation of the INEL SDA are as follows: a) no action, b) leave-in-place with improved environmental barriers, c) retrieval with off-site storage of untreated waste, d) retrieval with processing and storage off- or on-site, and e) another, as yet unidentified, in-situ technology or combination of technologies. Of these alternatives d) and e) are currently considered the most viable and environmentally 
responsible alternatives. As a result, EG\&G-ID has initiated studies to help identify viable treatment technology options. A report (Thermal Process 1991) involving an evaluation of thermal treatment processes ranked ISV higher than other alternative technologies due to its versatility, level of development, high quality of the resulting waste form, and low cost. Other technologies may be identified as part of the BWID in the future, which may result in additional alternatives to the ISV technology both for the SDA and buriedwaste remediation in general. A combination or integration of a number of viable technologies may well be the "best" option.

\subsubsection{Expected ISV Performance}

ISV has been shown to be an effective process for treating contaminated soils and trenches (Oma et a1. 1989; Carter et a1. 1987). In addition to several engineering-scale tests, two in situ vitrification field tests were conducted on simulated buried waste pits during June and July 1990 at INEL (Callow et al. 1991). The overall objective of the two tests was to assess the general suitability of ISV to remediate the type of waste found at INEL's SDA. In particular, these tests, as part of a treatability study, were designed to provide essential information on the field performance of the process under conditions of significant combustible and metal wastes and to test a newly developed electrode-feed technology. The tests were successfully completed, and the electrode-feed technology successfully processed the highmetal-content waste. Test results indicate the process is a feasible technology for application to buried waste. (Detailed information on all the testing performed to date is included in the Appendix.) Further work is needed to close technical issues (as identified generally or for specific operational units) before the ISV process can be transferred to DOE's Environmental Restoration (ER) division as a remediation process for buried wastes.

\subsubsection{Comparison of ISV in Meeting CERCLA Criteria}

Evaluating the ISV technology for application to buried waste requires assessing the rossible risks and advantages of the technology against the nine CERCLA criteria and then comparing ISV to other technologies and also to the risk of leaving the site unremediated. Significant work has been performed by 
an INEL ISV Steering Committee to identify technical issues relating to the buried-waste application (Stoots et a1. 1991). Some of the ISV technical issues relate to the feasibility of the ISV process while others are perceived as having possible adverse consequences to human health or the environment. Figure 3.1 shows the relationship between the primary categories of ISV technical issues and the nine CERCLA criteria.

The first seven CERCLA criteria address effectiveness, implementability, and cost. That is, how well does ISV reduce the risk at the site while not causing unacceptable risks of its own? Can remediation be accomplished in a reasonable time with the available resources? Does the cost/benefit ratio compare favorably to other alternatives? A remedy is effective when it can achieve acceptable levels of risk both in implementing the remedy and in the product formed.

A brief summary of the CERCLA criteria, as described by Stoots et al. (1991), is as follows:

1. Overall protection of human health and the environment -

Each remediation alternative is assessed to determine whether it can adequately protect human health and the environment from unacceptable risks by eliminating, reducing, or controlling exposures to levels established during the development of the remediation goals. Overall protection of human health and the environment draws on the assessments of other evaluation criteria, especially long-term effectiveness and permanence, short-term effectiveness, and compliance with applicable or relevant and appropriate requirements (ARARs).

2. Compliance with ARARs -

The alternatives are assessed to determine whether they satisfy ARARs, federal environmental laws, and state environmental or facility-siting laws. These include the Clean Water Act, Safe Drinking Water Act, Clean Air Act, RCRA, and Standards for Protection Against Radiation.

3. Long-term effectiveness and permanence -

The alternatives are assessed for the long-term effectiveness they afford, along with the degree of certainty that the alternative will prove successful. Factors that are considered include the following: 


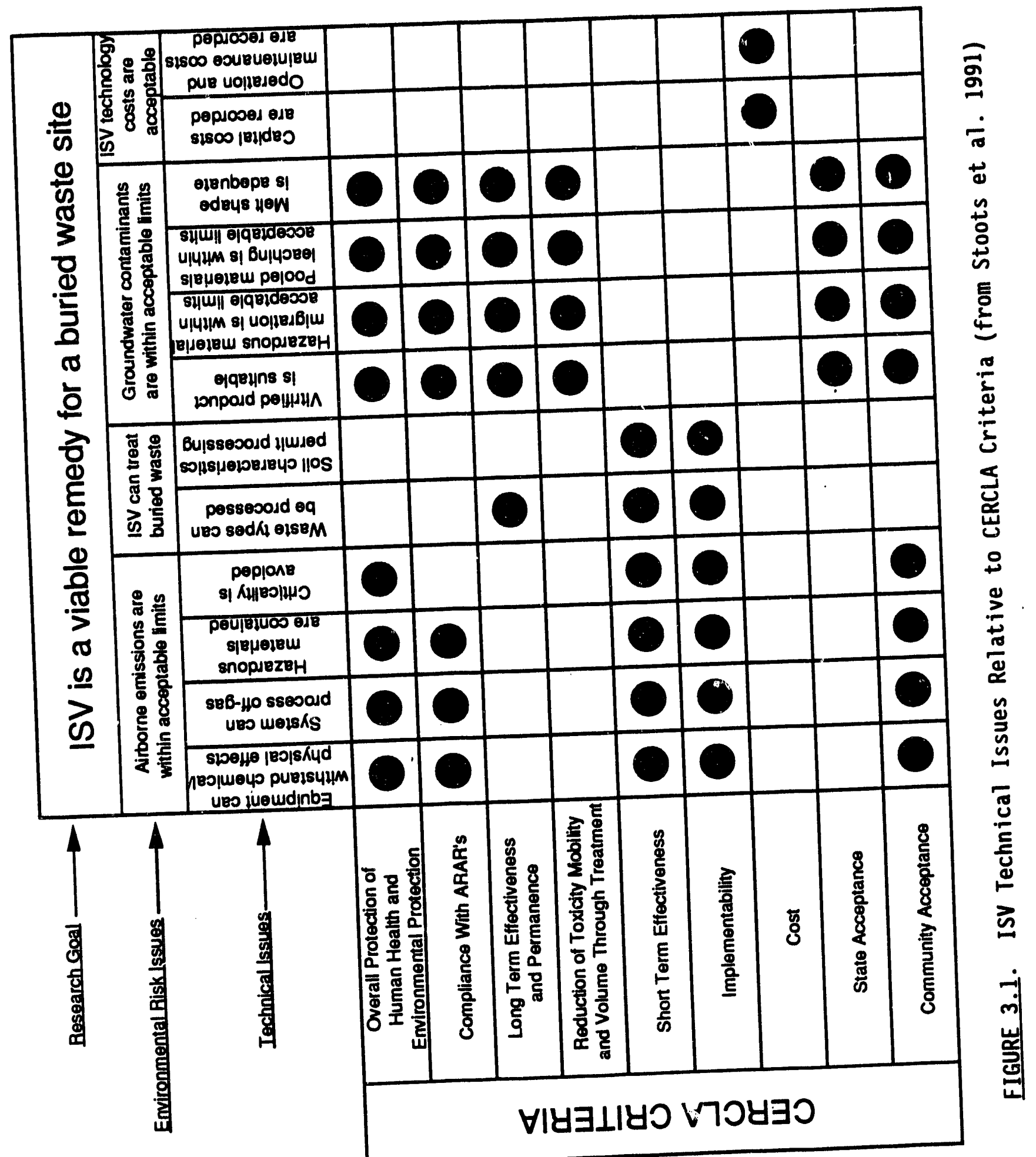

3.5 
a. The magnitude of residual risk remaininy iruin un. or treatment residuals at the conclusion of the remedial activities should be considered. The risk is to be evaluated in terms of the degree that the residuals remain hazardous, taking into account their volume, toxicity, mobility, and propensity for bioaccumulation.

b. Controls such as containment systems and institutional controls that are necessary to manage treatment residuals and untreated waste will be evaluated for adequacy and reliability.

4. Reduction of toxicity, mobility, or volume -

The degree to which the alternatives reduce toxicity, mobility, or volume is assessed, including how the different treatments address the principal threats posed by the site. Factors that are considered include the following:

a. the treatment or recycling processes the alternatives employ and the materials they will treat

b. the amount of hazardous substances, pollutants, or contaminants that will be destroyed, treated, or recycled

c. the expected reduction in toxicity, mobility, or volume of the waste due to treatment or recycling

d. the permanence of the treatment

e. the type ard quantity of residuals

f. the degree to which treatment reduces the inherent hazards posed by principal threats at the site.

5. Short-term effectiveness -

The short-term impacts of alternatives are assessed considering the following:

a. short-term risks that might be posed to the community during implementation of an alternative

b. potential impacts on workers during remedial action and the effectiveness and reliability of protective measures

c. potential environmental impacts of the remedial action and the effectiveness and reliability of mitigating measures during implementation

d. time until protection is achieved. 
The ease or altricuing vi inp.............

by considering the following factors, as appropriate:

a. technical feasibility, including technical difficulties and unknowns associated with the construction and operation of the technology, the reliability of the technology, the ease of undertaking additional remedial actions, and the ability to monitor the effectiveness of the remedy

b. administrative feasibility, including activities needed to coordinate with other offices and agencies and the ability and time required to obtain any necessary approvals and permits from other agencies (for off-site actions)

c. availability of services and materials, including the adequate off-site treatment, storage capacity and services; the availability of necessary equipment and specialists, and provisions to ensure any necessary additional resources; the availability of services and materials; and the availability of prospective technologies.

7. Cost -

The types of costs that are assessed include the following:

a. capital costs, both direct and indirect

b. annual operation and maintenance (0\&M) costs

c. net present value of capital and 0\&M costs.

The last two CERCLA criteria are State Acceptance and Community Acceptance. CERCLA requires that state and community input for the proposed remedy be solicited and addressed prior to selection of a remedy.

\subsubsection{Summary of Benefits to DOE}

ISV provides significant cost savings and risk-reduction benefits over conventional retrieval technologies due to in-place processing and the durability of its residual waste form. Rough order of magnitude (ROM) cost estimates have been developed as part of a system-design study (Mayberry et al. 1991) that evaluates the life-cycle costs for both in situ and ex situ processing options. This study specifically describes and compares the processes and resultant ROM estimates for in situ and ex situ treatments for buried waste. (The system-design study addresses other waste forms as we11.) 
The cost estimates include the remaining research and development costs for evaluation and resolution of technical and engineering issues, design costs, construction costs, and life-cycle operating costs.

The results of the system-design study for the treatment of INEL buried wastes are summarized in Table 3.1. The lowest-cost option involves using ISV as a final treatment, back-filling the site with soil (to fill the void created by volume-reduction of the wastes), and planting a vegetative cover.

Based on the results of this study, the ROM cost of ISV when used as a final treatment is about $16 \%$ of the cost for the least-costly ex situ system producing a vitreous waste form. Even if ISV is followed by retrieval of the ISV waste form, the cost is still only about $25 \%$ of the ex situ option. These costs include an estimate that $\$ 37$ million to $\$ 59$ million are still needed to

\section{IABLE 3.1. A ROM Cost Comparison of In Situ and Ex Situ} Vitrification Treatment Options

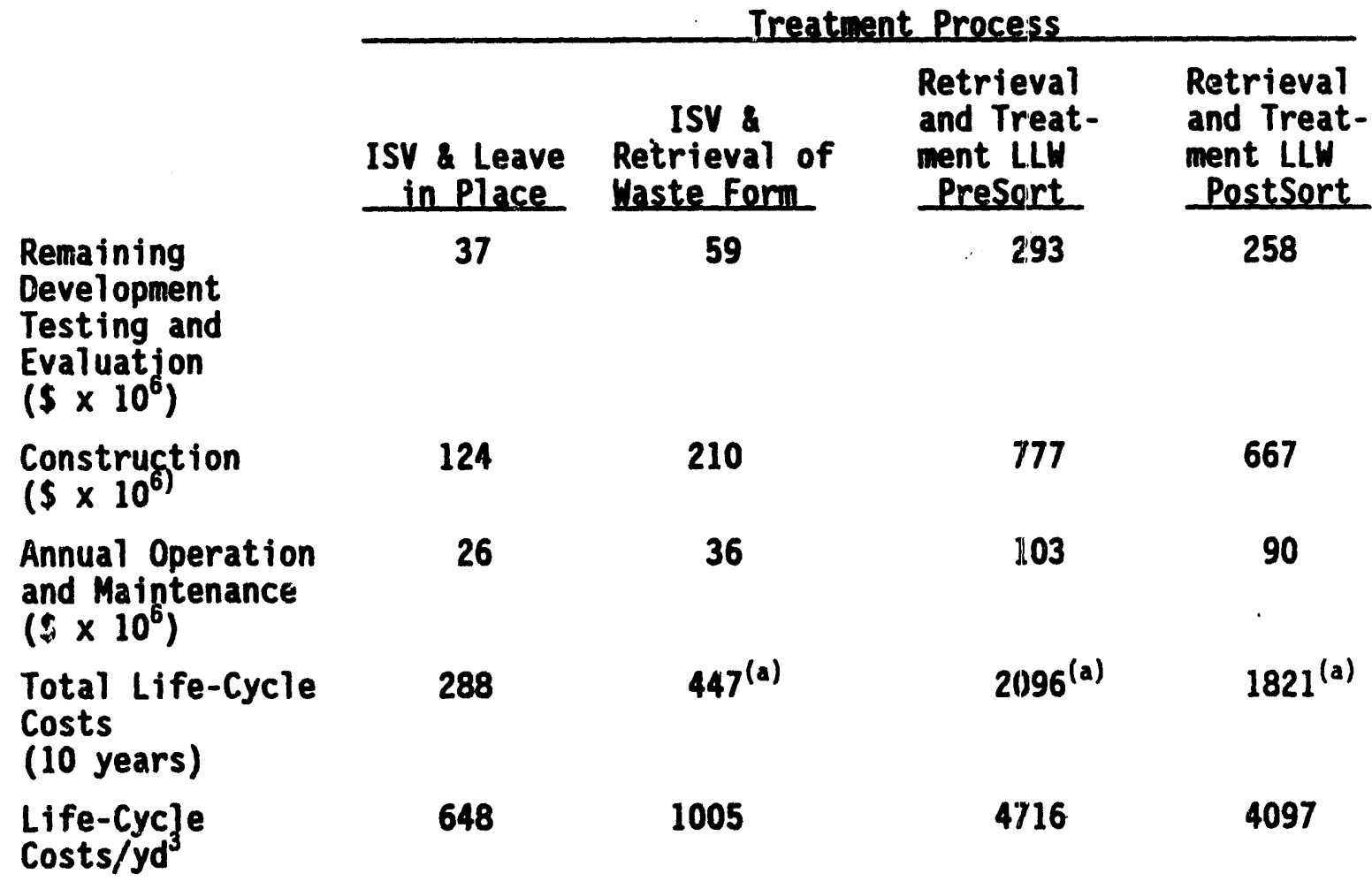

(a) Transportation to a final disposal site, disposal site costs, and facility decontamination and decommissioning are not included. 
develop the engineering parameters of the ISV process and optimize the equipment design prior to large-scale implementation.

ISV is significantly cheaper than retrieval methods because it is an inplace technology requiring no handling, packaging, storing, transporting, or disposing of the final waste. In addition, current practices of shipment to iicensed storage sites are meeting with growing public opposition as the public realizes that the wastes are not eliminated or stabilized as they are disposed, oniy contained for an interim period. Thus, communities are becoming increasingly concerned that the short-term economic and employment gains associated with disposal facilities may be more than offset by future environmental problems should tlie containment systems fail or the corporations operating the facilities abandon the sites. As a result, shipment of waste off of DOE sites is rapidly becoming a non-viable alternative.

The same judgement applies to risk. With the reduced number of handing steps, the overall operational risk to the public, the workers, and the environment will be reduced. Also, wich on-site processing and leaving the waste in place, the risk is not spread over a larger area or population base, as would be required when transporting the retrieved waste to a final repository or waste-treatment facility.

The residual waste form obtained from ISV processing significantly reduces long-term exposure risks to the public and the environment (Buelt et a1. 1987; Callow et a1. 1991). The process destroys hazardous organics and immobilizes heavy metals and the principal TRU contaminants in a durable glass matrix. The durability and quality of the glass matrix is the characteristic that allows consideration of a leave-in-place option for the processed waste. The durable glass-and-crystalline product physically and chemically resembles natural obsidian, which has been observed to be very durable for geologic time (Buelt et al. 1987; Callow et a1. 1991).

The ISV process can also be applied with a final step of conventional mining to remove the waste, with a savings over conventional retrieval methods. This alternative may be necessary where ARARs or other considerations dictate removal of the ISV product. The ISV-and-retrieve option would result in an enhanced retrieval capability in that significant volume 
reduction would be realized, contamination spread would be minimized, and the resulting product would be inert and relatively non-toxic. 


\subsection{TECHNOLOGY DEVELOPMENT/DEMONSTRATION NEEDS AND RECOMMENDATIONS}

\subsection{BURIED-WASTE TECHNICAL APPLICATION CRITERIA}

Implementation of ISV for remediation of buried-waste applications requires a broad range of technical and institutional capabilities covering all aspects of site remediation, from initial site characterization through final site operation and maintenance. Figure 4.1 illustrates the generic capabilities needed relative to the Superfund's model process. The generic capabilities noted may require many specific technical and institutional capabilities at subordinate levels. For example, the ability to predict residual product properties at the remedial design (RD) stage requires the ability to 1) predict the final product chemistry, 2) predict the expected cooling rates, 3) define the mineralogy that will crystallize given the melt chemistry and cooling rates, 4) predict melt uniformity, and 5) predict specific phase and aggregate leaching behavior.

To determine whether any development, demonstration, and/or engineering needs remain, the status of ISV capability in each of these generic areas must be evaluated relative to desired capability levels.

\subsection{TECHNICAL RESEARCH, DEVELOPMENT, AND DEMONSTRATION NEEDS}

The application of ISV to buried wastes is a relatively new process, and only limited testing has been conducted since development started in 1988. A total of three bench-, seven engineering- and two intermediate-scale tests on simulated buried wastes has been conducted (Arrenholz 1990). These tests have gradually increased in complexity and in how well the tests represent actual waste existing within the SDA. EG\&G-ID has developed a systematic approach (Stoots et al. 1991) to identify and prioritize technical issues and to identify an approach for closure for each issue. A summary of the primary or top-level technical issues and of the relationship of each issue to the nine CERCLA criteria is provided in Figure 3.1. Each of these primary issues may represent one or more subordinate technical issues. No attempt is made in this report to address each of these subordinate issues. Progress towards resolution has been achieved for many of these issues; however, additional work is required for closure in most cases. For this report, each of these 


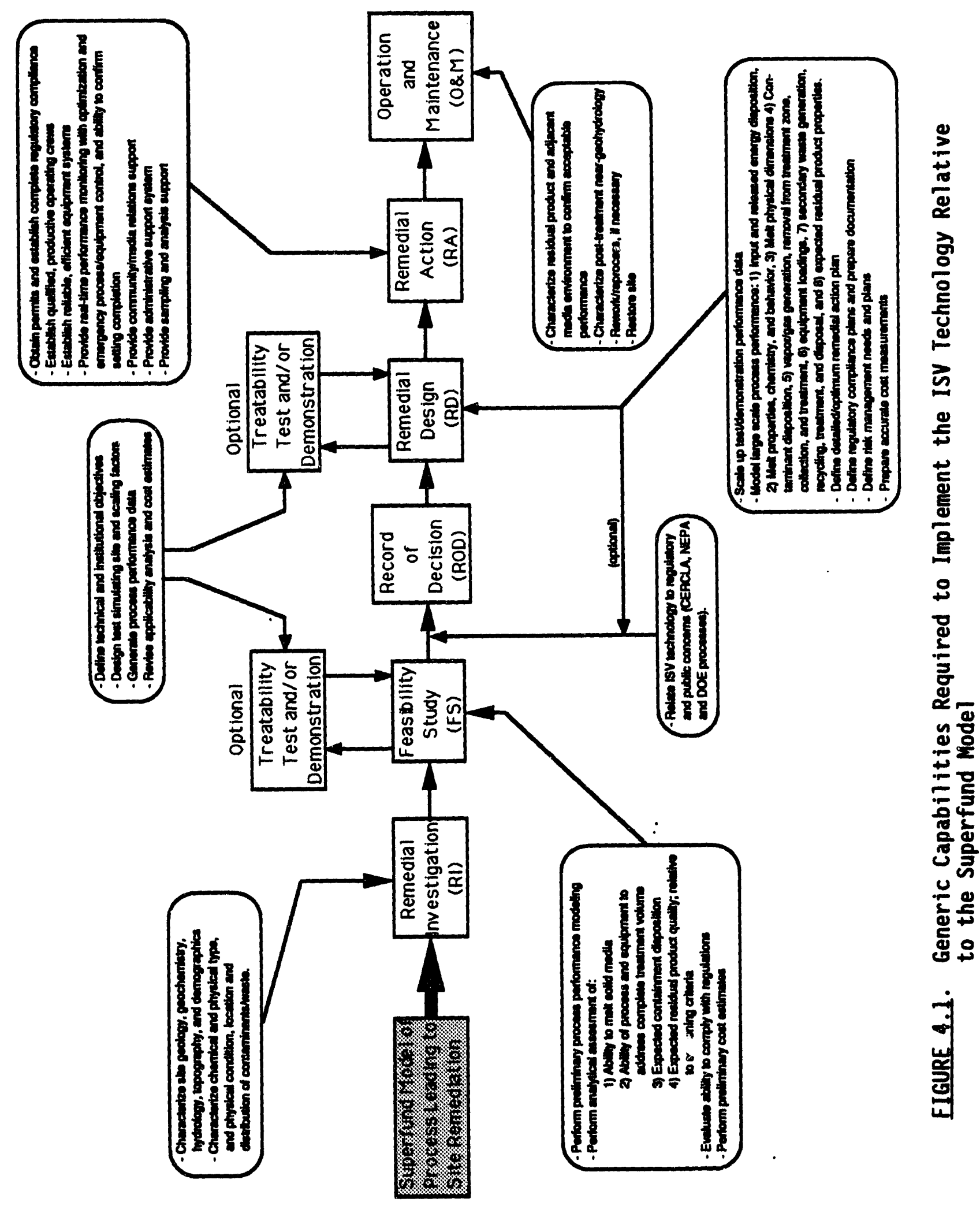


primary technical issues is summarized below. For additional information on the primary or subordinate issues, refer to Stoots et a1. (1991).

Issue - Equipment can withstand chemical and physical effects.

Characterization of waste types and analyses of the resulting effluents will be required to ensure that design specifications are adequate for the intended application. Current technology will probably be adequate for resistance to corrosion. Primary concerns involve the containment hood's ability to withstand the transient temperature and pressure spikes (including potential contact with moiten soil), which are characteristics of processing buried wastes with ISV. For additional information regarding equipment-design considerations, refer to Callow et a1. (1991).

Issue - System can process off-gas.

Steady-state off-gas releases during vitrification can be adequately treated using existing treatment technology. However, transient releases may generate peak off-gas concentrations of organic, inorganic, or radioactive waste species in either particulate or gaseous form; these transient surges of off-gas could challenge current treatment-system designs ${ }^{\text {(a) }}$ (Callow et al. 1991). Numerous tests have been conducted in which steady-state or average off-gas compositions have been measured (Oma et al. 1989). However, additional testing will be needed to measure the peak concentrations of waste species to determine the design requirements for the off-gas treatment systems. (Additionally, modeling can be an effective tool to help assess the capability of a proposed off-gas treatment system design.) It is probable that modifications to DOE's reference large-scale system design will be necessary to effectively treat transient effluents. For example, the addition of an after-burner in the off-gas line would help to ensure that all organic species in the off-gas stream are effectively destroyed.

Issue - Hazardous materials are contained.

Transient gas releases that are characteristic of ISV of buried wastes challenge the containment system (Callow et al. 1991). These transient releases, accompanied by temperature and/or pressure spikes, can cause hood pressurizations that may lead to the release of untreated off-gas to the environment. Additionaliy, splatter of molten soil can damage the hood and release off-gas. The design of the containment system must be developed to accommodate these transients and be sized to extend well beyond the

(a) Bergsman, T. M., and J. W. Shade. Draft 1991. Fifth Engineering-Scale In Situ Vitrification Test of Simulated INEL Buried Wastes. Pacific Northwest Laboratory, Richland, Washington. 
thermally affected zone to collect fugitive emissions. Modeling, test data, and engineering analyses will be necessary to optimize the design of the containment system. An initial functional and operational specifications document has been developed by EG\&G-ID and PNL, and EG\&G-Idaho has developed a preliminary design for a containment hood for buried-waste applications.

A scenario involving an underground fire could result in the release of fugitive emissions beyond the bounds of the containment hood. Test results (Callow et al. 1991) indicate that this is a low probability event for the common waste types and configurations. However, waste configurations involving organic materials in the presence of an oxidizer may be sufficient to sustain an underground fire. Additional evaluations will be required to determine if underground fires are possible.

Issue - Criticality is avoided.

Previous efforts have been directed to assessing the possibility of a criticality occurring either in a melt or in the off-gas treatment system as radioactive materials released from the melt accumulate in the treatment system. A FY-90 study (a) concluded that sufficient concentrations of boron existed within the soils at the SDA to preclude the possibility of a criticality in the melt under most circumstances. Additional postulated mechanisms that could lead to a criticality in the melt include densification of fissile materials prior to melt encapsulation; however, this mechanism is considered highly unlikely. (Due to the highly oxidizing nature of the actinides, a criticality resulting from the reduction of metal oxides in the melt is considered remote.) The design of the offgas treatment system combined with appropriate operational and maintenance procedures can preclude a criticality in the off-gas treatment system. Additional evaluations of this high-priority issue will be required. However, the probability of a criticality is considered remote.

Issue - Waste types can be processed.

The wide range of waste types within the SDA and the potential variability of wastes encountered in each ISV setting will influence the composition of the melt, potentially resulting in a product of varying durabilities. Operational difficulties may be encountered if layers of containers of either highly resistive or highly conductive materials are encountered. This issue has been

(a) Libby, R. A., et al. 1990. ISV Criticality Safety Analysis of INEL Soil. Informal Report, Pacific Northwest Laboratory, Richland, Washington. 
Targely addressed by the testing performed to date ${ }^{(a)}$ (Shade and Farnsworth 1990; Callow et al. 1991); positive results have been obtained for all waste forms tested thus far. Additional testing will be required on selected remaining waste forms to confirm that those waste forms can be processed safely and effectively.

Issue - Soil characteristics permit processing.

If sufficient soil is available, ISV will be capable of processing buried wastes. It may be necessary to add overburden prior to operations, or, in some cases, it may be necessary to add soil or other glass-forming materials during processing or prior to hood remova1. One potential problem identified during the FY-90 intermediate-scale field tests (Callow et al. 1991) involved the uncovering of waste forms adjacent to the subsided region of the melt. This situation could lead to contamination-control problems and increase the difficulties associated with post-melt operations. Full-scale remedial operations would likely be enhanced with a capability to add soil or glass-forming materials during processing to prevent adjacent waste from becoming exposed.

Issue - Vitrified product is suitable.

Significant efforts during FY-90 and FY-91 have been directed at determining the behavior of the ISV product resulting from the simulated buried-waste tests. Results to date are extremely positive in that the durabilities of the ISV product greatly exceed the durability of many natural analogs such as obsidian and basalt. In addition, the durability of the ISV product typically would exceed the durability of a high-level waste form (Shade and Farnsworth 1990; Callow et al. 1991; McGrail and Bates 1991). However, additional work will be required to address the durability of a product representing higher localized concentrations of certain waste types. During previous tests involving contaminated soils, convective mixing resulted in a relatively homogeneous distribution of the waste species in the product. However, this homogeneity may not always result for buried-waste applications. Since testing to date has been limited to simulated materials and surrogates, a final product-evaluation effort will be required to demonstrate the durability of product containing representative concentrations of plutonium and other actual wast a species.

Most metallic waste forms will melt when encompassed by the molten soil and will either dissolve into the molten soil or remain as a separate metallic phase (depending on redox conditions and kinetics). Metals that remain as a separate phase will have a greater density than molten soil and will form a pool (as a separate phase)

(a) Bergsman, T. M., and J. W. Shade. Draft 1991. Fifth Engineering-Scale In Situ Vitrification Test of Simulated INEL Buried Wastes. Pacific Northwest Laboratory, Richland, Washington. 
at the base of the melt. The metal phase will solidify as the block cools. The composition of this metal phase can vary greatly but is generally predictable based on reduction potentials of the waste species that are being processed (Shade and Farnsworth 1990; Callow et al. 1991). The durability of this metallic phase needs evaluation since it could potentially consist of a variety of regulated materials. (Because of the reduction potential of plutonium, it is virtualiy impossible to reduce plutonium metal in an ISV me1t; fortunately, however, plutonium will remain as an oxide distributed in the glass phase.)

Issue - Hazardous material migration is within acceptable 1 imits.

Semi-volatile and volatile hazardous waste components could be influenced by the thermal gradients advancing ahead of the melt front, increasing the mobility of these species in the surrounding soils. In addition, the rapid depressurization of buried containers of volatile materials could result in enhanced transport of hazardous materials. Testing to date on engineering- and intermediate-scale tests (Shade and Farnsworth 1990; Callow et al. 1991; Liikala 1991) indicates that the potential for contaminant transport exists, but it does not occur to a significant or consistent degree. It is also noted that many ISV tests (Dragun 1990) and tests of other in situ thermal treatment technologies have indicated the lack of contaminant migration into the adjacent soil, and have indicated that thermal treatment even draws vaporizable contaminants from the adjacent soil into the treatment zone (Dev 1988). However, questions exist regarding the fundamental transport mechanisms involved. Mechanistic studies conducted during 1990-1992 have resulted in the identification of key parameters that control transport (Kuhn 1992); however, additional laboratory testing will be required to finalize the transport model. It will be necessary to confirm the mechanistic behavior and evaluate this issue with respect to applicable regulations.

\section{Issue - Characterization of melt shape and depth is adequate.}

The shape and depth of the melt is a key issue in determining whether all of the waste inventory has been treated. Depth can be measured based on the length of electrodes inserted into the molten soil. However, meit shape is more difficult to measure in a real-time mode. Acoustic tomography has been tested during intermediate-scale field tests (Callow et al. 1991). However, additional testing or evaluation of other technologies may be needed to provide a means to verify both the shape and depth of the melt. Efforts associated with other ISV applications are directed at improving the predictive capability for melt shape and at achieving greater depth. 
Issues - Capital costs and operation and maintenance costs are recorded.

One of the nine CERCLA criteria involves the process of evaluating and documenting costs. Systems studies produced by EG\&G-ID out Tine development, capital, and operational costs associated with various technology applications, including ISV. More detail regarding cost is included in Section 3.2.4 of this report and in Mayberry et al. (1990). 


\subsection{IECHNOLOGY INSTITUTIONAL NEEDS AND RECOMMENDATIONS}

\subsection{EPA BURIED-WASTE INSTITUTIONAL APPLICATION CRITERIA}

EPA's primary criteria for evaluating the "institutional" acceptability of a technology for use at a specific site include regulatory acceptance and public acceptance. It is noted that the EPA evaluation criteria of implementability and compliance with ARARs are closely related to these two primary institutional criteria, and may also be considered as institutional criteria for the purposes of this report.

\subsection{DOE INSTITUTIONAL OBJECTIVES}

In addition to satisfying EPA and state regulatory criteria of an institutional nature, DOE has the additional objectives of ensuring effective transfer of the ISV technology to the commercial sector and ensuring development of an industrial partner commensurate with development of the technology for DOE needs.

\subsection{INSTITUTIONAL STATE OF THE TECHNOLOGY}

\subsubsection{EPA and State Requlatory Acceptance}

The ISV technology has obtained regulatory acceptance for both the DOE program and Geosafe's commercialization program. Several EPA regions and the state agencies have been supportive of the ISV development, testing, and demonstration work being performed through 1) PNL at Hanford, 2) EG\&G-ID at INEL, 3) Martin Marietta Energy Systems at ORNL, and 4) Geosafe treatability testing and remedial operations. This regulatory support has been indicated by the provision of R\&D permits under both the EPA and the Toxic Substances Control Act (TSCA) for processing of PCB-contaminated soils, and by authorization to proceed with various engineering-, pilot-, and large-scale tests.

For non-DOE commercial sites, the ISV technology has received support from various EPA Regions and states as indicated by selection of ISV as a preferred remedy at the sites in Section 5.3.2 of this report. These selections have involved the approval of EPA Regions IV, V, VI, VIII, and $X$ for the 
specific sites involved. They have also involved the approval of the states of North Carolina, Colorado, Utah, Tennessee, Texas, Washington, Michigan, and Illinois. State acceptance of a technology relates directly to the technology's capability to satisfy the pertinent state regulations, which are often the most stringent of the ARARs. Where evaluated thus far, ISV has had no difficulty satisfying state ARARs.

SARA mandates EPA to show strong, if not preferential, support to the demonstration and selection of "innovative" technologies in the superfund RI/FS process. Such support has been indicated by the above-mentioned ISV selections. Support is also evidenced by EPA's SITE and START programs, both of which provide technical support information and services to the EPA Regions. The SITE and START organizations have referred many inquiries to Geosafe as potential sites for use of ISV. In addition to SARA's mandate, regulatory support of a "hopeful" nature has also been shown toward the ISV technology because of its likely usefulness at difficult sites for which there are no other reasonable potential remediation alternatives.

The ISV technology is not presently considered highly implementable by the regulatory community. They recognize that only one large-scale ISV system has been available on a commercial basis, and that at this time the use of that machine is on hold pending resolution of the testing incident experienced by Geosafe during an equipment operational acceptance test.

\subsubsection{Public Acceptance}

ISV has received general public acceptance as indicated by 1) positive response at public hearings associated with the Superfund process, 2) public efforts to have ISV employed in place of incineration at two Superfund sites, 3) public acceptance at DOE hearings, and 4) generally favorable media coverage. ISV has been addressud at public hearings associated with the following sites: Pristine (Region V, Reading, Ohio), Parsons/ETM (Region V, Grand Ledge, Michigan), M-1 Holding Ponds at Rocky Mountain Arsenal (Region VIII, Commerce City, Colorado), Wasatch Chemical (Region VIII, Salt Lake City, Utah), and Northwest Transformer (Region X, Bellingham, Washington). There have been two negative hearings associated with sites where the Principle Responsible Parties (PRPs) have resisted the selection of ISV: the Anderson

\section{2}


Chemical site (Regton VI, Houston, lexas).

\subsection{IECHNOLOGY TRANSFER}

The ISV technology has been transferred to the commercial sector through the licensing of the technology by Battelle Memorial Institute. Battelle has created Geosafe Corporation to provide onsite ISV remediation services and associated testing and technical services for commercial applications. Geosafe has established ISV as an alternative within the hazardous waste remediation marketplace.

Although Geosafe does not perform R\&D, it does perform treatability/ pilot testing and demonstration work as required to qualify the technology for remediation of specific sites. Recognizing that the Geosafe work is generating information of interest to the DOE program, an informal consortium consisting of Geosafe, PNL, ORNL, and INEL has been established for information-exchange purposes, where allowed by proprietary and governmental restrictions. This exchange provision is instrumental in maintaining a high level of continued bi-directional technology transfer.

Geosafe has formally indicated its desire to serve as an "industrial partner" to DOE for the purpose of providing a commercial capability to support DOE's development, demonstration, and implementation needs. Geosafe made this indication by submission of its capabilities statement and letter of intent to EG\&G-ID during 1991.

\subsection{INSTITUTIONAL RESEARCH, DEVELOPMENT, AND DEMONSTRATION NEEDS}

Successful development and depioyment of ISV for application to buried waste will require that the institutional objectives of regulatory acceptance, public acceptance, and technology transfer be accomplished concurrent and commensurate with the technical development. The key issues involve both regulatory and public acceptance of the technology. A strategy is also needed for technology-transfer in order to carry the technology through resolution of the final R\&D-based issues, through the various intermediate demonstration stages, and finally on to full deployment for environmental restoration. An 
ultimately io an enviruinuerica, .....

strategy.

Regulatory acceptance of the ISV technology depends directly on the ability of the technology to satisfy state and federal ARARs, and the awareness of the regulatory community that the technology does, indeed, do so. Since many different regulators and regulatory functions are involved with reviewing and approving use of ISV at various DOE sites, the need in this area requires development of information pertinent to regulatory interests and a continuing educational/promotional campaign directed to the regulators.

In a somewhat similar manner, the area of public acceptance requires a comprehensive and continuing flow of information to the public most concerned with a particular site and to related special interest groups regarding the ISV technology, its benefits relative to other technologies, and the specifics of its application at the sites of interest. There is a need to communicate this information to the public on a continuing basis, as well as at regulatory-required public hearings relative to specific sites.

The institutional need of transferring ISV technology to the commercial sector cannot be expected to happen efficiently without determined effort. A formal process for the transfer is needed. In addition, and perhaps equally or more important to DOE, there is the need for reverse technology transfer from the commercial side to the DOE program. This latter need will increase in importance as the commercial offerers of ISV gain experience beyond that available within the DOE ISV community. Again, there should be some formal method for obtaining that information for use by DOE. The "industrial partner" approach planned by EG\&G-ID/INEL promises to help satisfy this latter objective; it may not, however, be sufficient in itself. Once and if multiple commercial offerers of ISV remedial services are available and several remedial operations are ongoing at multiple DOE sites, systematic management of these activities will be necessary to ensure that technological innovations and lessons learned are integrated throughout all the relevant ISV operations. 


\subsection{PROGRAMMATIC REOUIREMENTS TO SATISEY NEEDS}

\subsection{DEFINITION OF DOE PROGRAMS AND TASKS INVESTIGATING ISV}

Several tasks under the Buried-Waste Integrated Demonstration and the ISV Integrated Program have been involved with the development of ISV for the buried-waste application. However, consistent with the current focus of the ISV Integrated Program, which is to resolve the remaining issues associated with contaminated-soils applications, advanced ISV applications such as use on buried waste are not being pursued through the Integrated Program. Work in FY -92 relating to buried wastes was limited to closeout of work residual from FY-91. In FY-92, a buried-waste technology development: plan that outlines a development strategy for this ISY application was prepared (Nickelson et al. 1992). To implement the tecthology-development plan, funding support for ER and OTD are still being pursued.

Up to FY-92, the primary development tasks were collaborative efforts involving INEL and PNL. INEL had the lead for the proyram via BWID. Geosafe Corporation provided technical support services ranging from design support to testing services.

Additional OTD-funded tasks investigating ISV for other applications contribute both directly and indirectly in support of closure of technical issues for buried-waste applications. Data and information produced during testing, modeling, or other evaluations contribute to the body of ISV knowledge.

The ISV Integrated Program, established in May 1991, has begun to provide a more formalized and systematic means of coordinating the various ISV research activities, including those funded by industry and foreign governments. This program is designed to focus development toward the needs of the end-user, to coordinate activities by focusing resources on critical development needs, to maximize cost effectiveness, and to build greater synergism among individual tasks. The program also provides a forum to allow technical exchange and coordination among the technology's developers. 


\subsection{PROGRAMMATIC ISSUES AND PROGRESS}

Numerous technical and institutional issues confront the development and application of any technology for waste-remediation activities. The end-toend requirements applicable to any technology include not only the technical and health and safety issues, but also the less tangible regulatory, legal, societal, and financial issues. The ISV Buried-Waste Program, managed by EG\&G-ID in collaboration with the Buried Waste Integrated Demonstration, has been addressing all the programmatic aspects in the ISV buried-waste application/development process via a treatability-study strategy in accordance with the CERCLA. The nine criteria of CERCLA, discussed earlier in this report, outline the key areas necessary to address the system's end-to-end requirements. This approach helps to ensure that an efficient, complete and compatible technology-ready for application-emerges for use by ER. Yearly reports prepared by EG\&G-ID summarize the progress in these efforts (Arrenholz 1990).

\subsection{PROGRAM BUDGET PROJECTIONS}

Development costs since 1988 are outlined in the literature (Arrenholz $1990)$ and total $\$ 1.25$ million in FY-88, $\$ 8.27$ million in FY-90, and $\$ 10.6$ million in FY-91. Since funding for FY-92 has been significantly reduced, progress during FY-92 will be limited. Since the buried-waste application is not being actively developed at this time, progress in developing this particular application will be extremely limited in FY-93 and beyond unless additional resources are obtained. Remaining development, testing, and evaluation costs, estimated by Mayberry et al. (1991), are anticipated to require between $\$ 37$ million to $\$ 59$ million (see Table 3.1 ); based on the Mayberry analyses, however, much of this cost would be distributed over several years among many organizations. This total is 4 to 8 times less costly than the development costs anticipated for other treatment alternatives and, considering total life-cycle costs, is between 5 to 10 times less costly than other alternatives (Mayberry et al. 1991).

The ISV Technology Development PIan for Buried Waste concludes that an additional amount of $\$ 24.7$ million will be required to develop and demonstrate ISV for INEL buried wastes during the 1993-through-1998 time frame (Nickelson 
et a1. 1992). Of this amount, it is recommended that $\$ 6.7 \mathrm{million}$ be funded by the DOE Office of Technology Development and $\$ 18$ million by DOE Environmental Restoration. These cost projections are in addition to the $\$ 10.2$ million projected by the ISV-IP to resolve the issues remaining for contaminated-soils applications.

\subsection{PROBABILITY OF PROGRAM SUCCESS}

Significant technical progress, including closure of several technical issues, has been achieved since the development of ISV for buried-waste applications was initiated in 1988. Advances in equipment-design and processknowledge regarding the behavior of the ISV process indicate that many technical issues investigated to date have been, or can be, satisfactorily addressed. Results of testing and analyses to date have established no critical issues that would preclude the use of ISV on buried wastes. Institutionally, public and regulatory acceptance is positive, and life-cycle costs are anticipated to be significantly less than those of alternative treatment technologies. If retrieval is institutionally desired, the vitrified product would represent a waste form of significantly reduced risk, making retrieval and subsequent treatment or disposal less hazardous. It is likely that some buried-waste forms or burial configurations would not be amenable to treatment by ISV; however, a vast majority of DOE's buried-waste sites are likely treatable with ISV. 


\subsection{RECENT ADVANCES IN PROCESS EQUIPMENT FOR ISV IECHNOLOGY}

The chief obstacles to processing buried waste with in-situ vitrification technology have been 1) effective processing of high-metal-content waste and 2) mitigating the effects of transient gas releases and their potential for upsetting the process. The development of electrode-feeding has addressed the first obstacle, and two other developments appear to be able to address the latter two obstacles. These advances hold much promise towards the eventual application of ISV to buried waste. (a)

The first of these developments deals with controlling the positioning of electrodes. The other two (water-spray suppression-systems and positivepressure electrode seals) are concerned with containing a gas release once it has occurred. Each of these advances will be discussed in turn. Emphasis will be given to how each of these can affect the application of ISV to buried waste.

\subsection{ELECTRODE-FEEDING SYSTEM}

Until 1990, it was the accepted practice of ISV operations to use fixed electrodes. These electrodes were normally of a composite nature: a metallic core, normally molybdenum, surrounded by an outer sheath of graphite. Such electrodes are costly, from a materials and installation standpoint, and difficult to fabricate in the field. In 1989 the ISV group at PNL started to experiment with a tachnique whereby solid graphite electrodes could be fed continuousiy into the ISV melt. As the depth of the melt increased and/or the electrodes were consumed, new sections of graphite could be added to the top of the electrode. The electrode-feed system concept was tested in several engineering-scale tests before being successfully demonstrated in a joint INEL/PNL pilot-scale demonstration (Callow et al. 1991).

What eventually evolved from this work is the electrode-feeding device depicted in Figure 7.1. The principle of operation is simple. There are two

(a) Luey, J., W. O. Heath, T. D. Powe11, and R. L. Richardson. Draft 1991. Engineering Scale Operational Acceptance Test Report. Pacific Northwest Laboratory, Richland, Washington. 


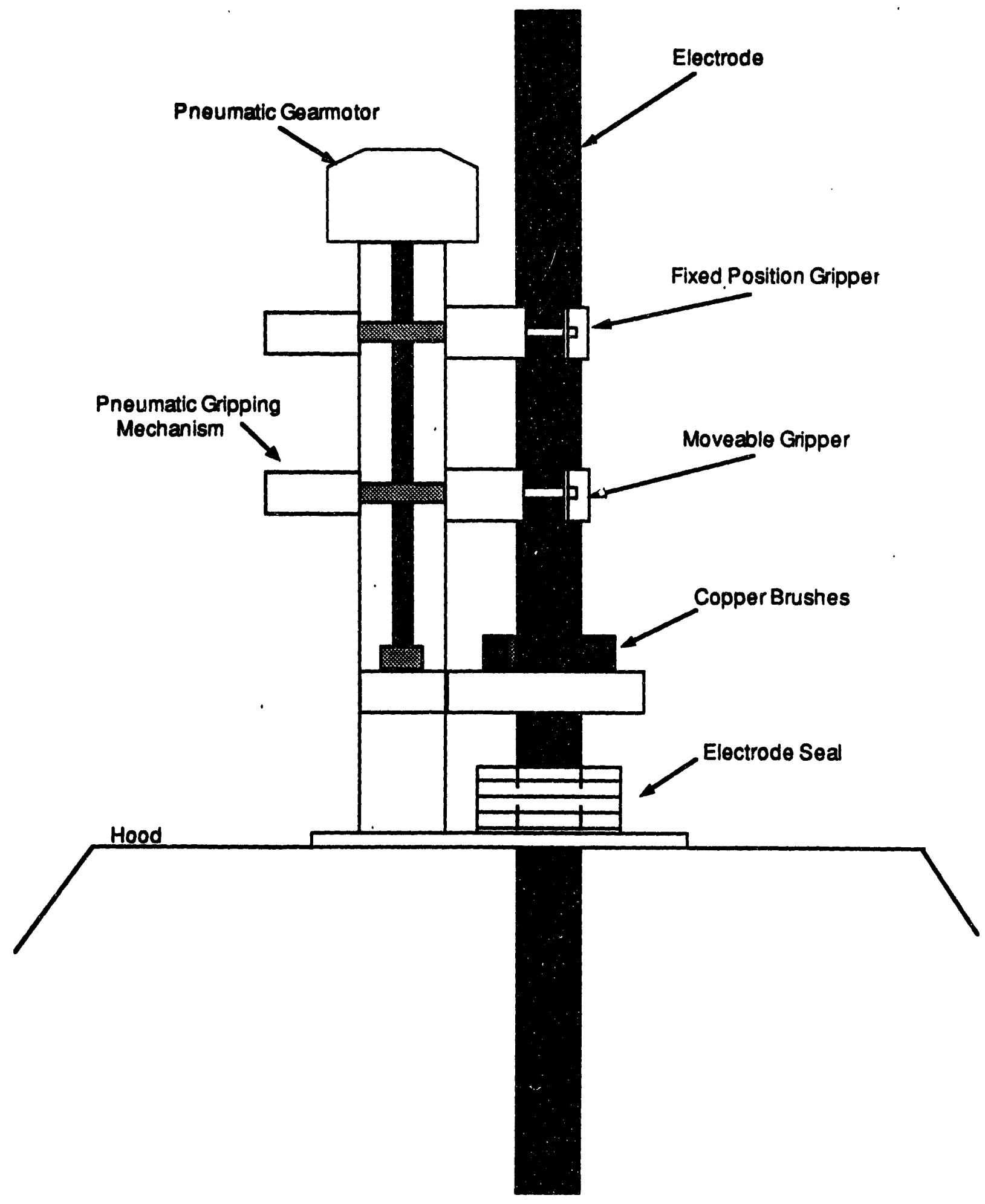

$\checkmark$

Fixed Position Gripper

EIGURE 7.1. Engineering-Scale Electrode-Feeding Mechanism 
grippers which, by the action of pneumatic actuators, grip the electrodes. One of these grippers, the upper one, is rigidly mounted to the device's framework. The other, lower, gripper is mounted on a vertical, squarethreaded shaft. One end of this shaft is attached to a pillow block, while the other end is connected to a pneumatic gearmotor. Rotating the shaft via the gearmotor moves this gripper vertically. By releasing the upper gripper and engaging the lower gripper, the operator can move the entire electrode up or down. The electrode-feeding devices are powered and controlled entirely by pneumatics. Electrical isolation is thus ensured, and there is no need to interrupt power to the melt when conducting electrode-movement operations. Spring-loaded copper brushes maintain electrical contact between the power supply and the graphite electrode.

There are a number of benefits to the electrode-feed system. Cost savings result from the use of inexpensive graphite electrodes, and intrusive drilling into a waste site to install electrodes is eliminated. (Installation of fixed electrodes requires drilling casings into the waste site to the target depth and inserting the electrodes before powered operations commence.) In addition, there are other important advances that are not intuitively obvious. Chief among these is the ability to control the downward progression of the melt. This has important control implications for the entire ISV process. Of particular importance are the advantages this control presents for the problem of buried wastes. For example, if it is known that a layer of buried drums exists at a certain depth, the ISV operator can manipulate the depth of the electrodes and their power input so that the drums are allowed to heat gradually in advance of the melt's front. In this manner, volatile species are volatilized and released through the soil to the containment hood before the drums come into contact with the melt. Unnecessarily vigorous off-gassing through the melt is thus avoided. Another advantage of electrodefeeding that is of particular relevance to buried waste is the ability to circumvent electrode-shorting caused by molten metal pooling at the bottom of the melt. This can happen when a site containing a large volume of metal or metal containers is processed. As the melt proceeds, the molten metal will gravitate towards the bottom of the melt since molten metal has a greater density than molten soil. If the pool grows large enough, direct, 
low-impedance electrical contact is initiated between electrodes, causing the short circuit. With fixed electrodes, this condition is difficult, if not impossible, to circumvent. Electrode-feeding, however, allows the operator to simply raise the electrodes to the point where the condition rectifies itself, just above the molten pool. Because molten metal is an excellent conductor of heat, the melt will continue to increase in depth. Another benefit of electrode-feeding is that the technology allows the use of depth-enhancement techniques such as the conceptualized hot-tip electrode. Since the hot-tip electrode would be designed to distribute the electric current only at the bottom of the melt pool, it could not be used as a stationary preplaced electrode.

The 1990 pilot-scale demonstration report (Callow et al. 1991) details the successful performance of the electrode-feed system.

\subsection{WATER-SPRAY SUPPRESSION-SYSTEM}

The processing of contaminated soils using ISV will normally result in a relatively steady-rate of off-gassing. These gases are contained by a negative pressure hood and vented to an off-gas processing system. Proper hood and off-gas system design in conjunction with this steady-state situation will result in a system that performs within established temperature and pressure parameters. Occasionally, however, transient gas releases from sealed containers at the base of the melt will result in transient temperature and pressure spikes within the off-gas system, particularly in the hood. For contaminated-soils applications, these transients are relatively minor and are easily accommodated within the design parameters.

Such transients, however, can be expected to be greater in frequency and magnitude when dealing with a site that contains buried waste, particularly in sealed containers. The off-gas system would have to be designed to deal with these transients. One option would be to simply design greater capacity into the system. For the off-gas processing system, this is the preferred alternative as it would not entail a prohibitive increase in physical size or capital outlay. The containment hood, however, is another matter. The cost of the hood increases rapidly with size. A hood large enough to control transient pressure and temperature spikes would be costly and difficult to

\section{4}


erect and move at the remediation site. Other methods to mitigate the effect of these transients had to be evaluated.

One promising method was evaluated during an engineering-scale test at PNL in September of 1991 (Luey et a1. 1991). The test used a water-spray suppression-system. The theory is that a fine spray of water injected into the hood plenum would reduce both temperatures and pressures in the hood during a transient event. Heat evolved from the transient would be utilized in converting the liquid water spray into steam. Calculations show that the pressure increase resulting from the specific volume increase of vaporizing water would be more than offset by the decrease in temperature and pressure, following ideal gas laws. As can be seen in Figure 7.2, decreases in the offgas temperature correspond to decreases in hood pressure. Later on, however, pressure spikes can be seen in Figure 7.2. This has been attributed to the

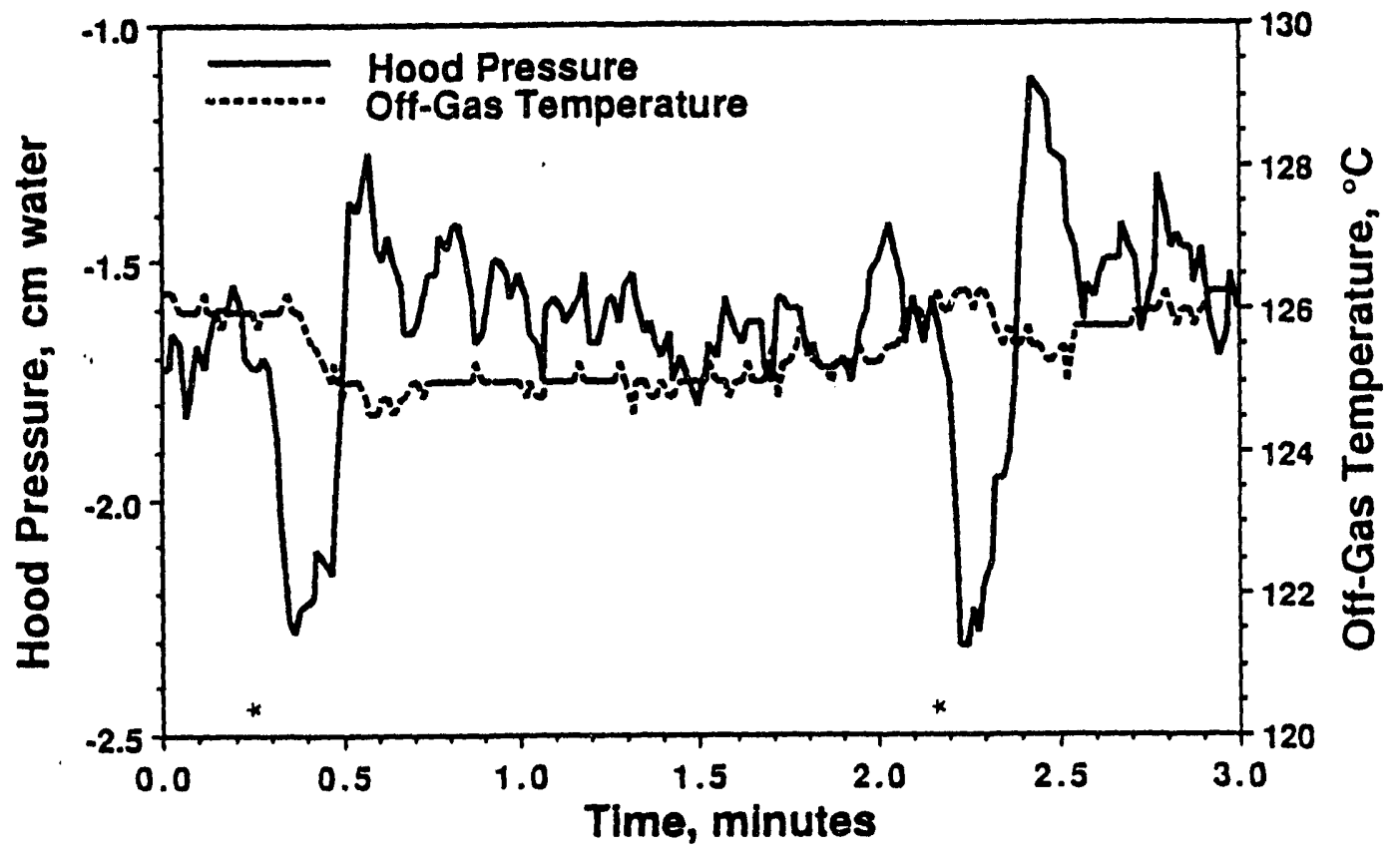

EIGURE 7.2. Water-Spray Suppression-System Trials 
water spray not vaporizing until it came into contact with the melt surface. Heat of vaporization in this case was taken from the melt and not the air in the plenum. Therefore, the water flashed into steam with no corresponding decrease in plenum air temperature, and thus the pressure in the plenum rose.

The above case, however, is not representative of what would be expected from a transient event in the field. The engineering-scale test from which these data were taken was a steady-state test with relatively low plenum air temperatures. The driving temperature potential in the above case is only on the order of $25^{\circ} \mathrm{C}$. The water spray in such a case might not vaporize before falling to grade level and contacting the melt. Field-scale tests generally would provide a much greater temperature differential (approximately $200^{\circ} \mathrm{C}$ ) to drive the vaporization of water much more rapidiy. A transient event can be expected to have much greater temperature-driving potentials and vaporize the spray with heat extracted from the plenum atmosphere. One way to ensure that the water spray would vaporize readily would be to preheat the water before it is injected into the hood plenum. In this manner, heat that would otherwise be used to heat the water from its source temperature to $100^{\circ} \mathrm{C}$ could be utilized entirely as heat of vaporization.

Transient off-gas events characterized during the pilot-scale field demonstration conducted at INEL on simulated buried wastes revealed that the transient events were relatively slow to develop (over a period of 5 to $10 \mathrm{~s}$ ) (Callow et a1. 1991). By simply controlling the release of water spray from a pressurized, solenoid-controlled spray system, water spray could be introduced to the containment hood in less than $1 \mathrm{~s}$. The solenoid controlling the valve could be activated at a predetermined hood vacuum set-point via a pressure transducer signal well before the hood reached positive pressure.

\subsection{ELECTRODE SEALS}

A key potential release pathway for untreated off-gas during a transient pressure event is the electrode penetration ports on the off-gas hood. Currently, these ports are sealed with rings of high-temperature fabric through which the electrodes are inserted. The rings are sized so as to provide a tight seal against the electrodes. Under normal operating conditions, these seals are sufficient. Under transient-loading conditions, it is possible for 
the fabric rings to pull away from the electrodes and thus break the seal. Under extreme conditions, the fabric rings may rupture. In either case, a seal is not maintained, allowing untreated gases and particulate to escape the hood plenum.

Since the processing of buried wastes involves a significant risk of producing both gas-release transients coupled with hazardous and radioactive materials, it is important to mitigate the possibility of containment breaches due to inadequate electrode seals. To this end, an active electrode seal was tested during the same operational acceptance test conducted in September, 1991, described above. A brief schematic diagram of the seal tested is shown in Figure 7.3 .

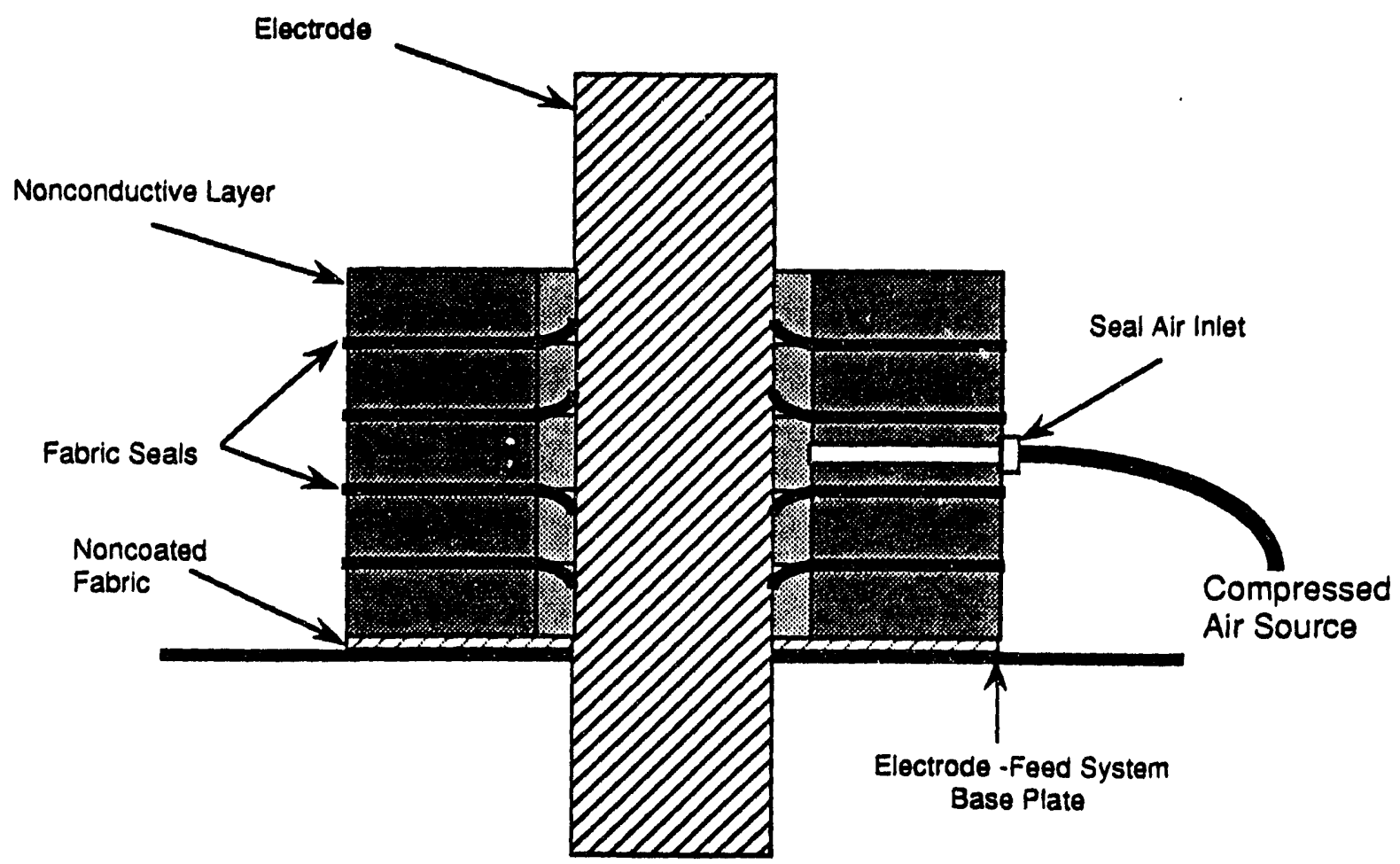

FIGURE 7.3. Diagram of the Pressurized Electrode Seal 
The theory behind the operation of this device is that a positive air pressure maintained in the annulus between the nonconducting plates and the electrodes will create an influx of air into the hood plenum should the seal fail. This device performed very satisfactorily during the acceptance test. The air flow required to maintain a set point air pressure of 3 psig within the seal showed very little variation. This indicated that the seals were relatively unaffected by temperature fluctuations within the ISV unit and that the repeated movement of the electrodes past them did not damage them. Posttest inspection showed only minor wear of the fabric seals.

The seal pressure can be set to exceed any conceivable pressure that could result in the hood from a transient gas release. In this way, air from the seal will aiway: flow into the hood regardless of the conditions in the hood, thus eliminating the electrode ports as potential release points. Only relatively low seal pressures of less than a few psig would be required to accommodate any conceivable transient events. 
As a result of over 150 ISV tests and a variety of engineering analyses, operational capabilities for DOE applications of the ISV technology have been established for contaminated-soil applications (Buelt and Thompson 1992). Detailed below are the present capabilities of the technology known to the ISV Integrated Program for contaminated-soils applications; these statements of capability are based on the present understanding of the current state of the technology as demonstrated with existing equipment. (a) These capabilities are included here to provide a baseline for evaluation relative to requirements for buried-waste applications. As technological advances are realized, these operational capabilities will be revised accordingly.

\subsection{SOIL TYPES}

ISV is currently applicable to contaminated soils and sludge regardless of whether they are sand, silt, or clay. Even rocky soils are melted by the process. However, special monitoring and/or analyses must be performed when vitrifying silty soils or non-swelling clays. These materials generally have lower permeabilities (i.e., less than $10^{-3} \mathrm{~cm} / \mathrm{s}$ ) even after being dried out (Buelt et al. 1987). Sandy soils and clays that shrink and crack when dried are relatively permeable. They easily allow the release of water vapor that evaporates from the soil being vitrified, thus precluding the potential for pressure buildup of water vapor beneath the melt in excess of the static head pressure of the glass. The ISV Integrated Program is planning to refine operational capabilities through analysis and experimentation for the lower permeability soils and sludge. In addition, Geosafe Corporation, the private industrial supplier of ISV remediation services, is currently having independent modeling studies performed relating effects of permeability, soil type, melt rate, and moisture content in order to define acceptable operating regimes for such soils.

(a) The data about current ISV capabilities detailed in the following subsections are drawn largely from Buelt and Thompson's Spectrum 92 paper. 
ISV is generalily appilcavie iu su,...

Solls and sludge ranging from 4 wt\% moisture to 50 wt\% have been successfully vitriffed. The amount of water associated with silty soils or non-swelling clays becomes important in the analysis for application to these types of soils relative to the dry soil's capacity to vent steam to the containment hood. The process, however, is not applicable for soils that lie within a permeabie aquifer (i.e., greater than $10^{-4} \mathrm{~cm} / \mathrm{s}$ permeability), unless combined with a ground-water diversion or pumping technique during processing to limit the rate of water recharge to the treatment zone.

\subsection{SOIL COMPOSITION}

Because most soils and sludges are naturally composed of glass-forming materials such as silica, they are generally processable by ISV without modification. However, a minimal alkali content (i.e., combined $\mathrm{Na}_{2} \mathrm{O}$ and $\mathrm{K}_{2} \mathrm{O}$ content) of 1.4 wt\% is necessary (Buelt et al. 1987). Alkaline oxides are responsible for carrying the electrical current among electrodes in the molten state. Weathered soils with less than $1.4 \mathrm{wt} \%$ oxides require the addition and mixing of alkaline ma arials to lower the melting temperature and raise electrical conductivity. Additionally, excessive amounts of alkali can pose processing problems by lowering the electrical resistance in the melt, which reduces the melt temperature. The presence of large quantities of buried materials, such as nitrate salts, could result in a lowered melt temperature, which could inhibit additional processing of contaminated soils and wastes.

\subsection{DEPTH OF CONTAMINATION}

The ISV process has been demonstrated at depths of up to $5.8 \mathrm{~m}(19 \mathrm{ft})$ in relatively homogeneous soils. The achievable depth, however, can be limited under certain heterogeneous conditions, such as the presence of a rock or gravel layer where heat transfer is less efficient, or of a soil layer with significantly higher melting temperature than the overlying material. Depths of $4.3 \mathrm{~m}(14 \mathrm{ft})$ and $5.2 \mathrm{~m}(17 \mathrm{ft})$ have been achieved when rock layers existed at those depths. In addition, the relative density of the soils to be processed influences the achievable melt depth. Higher-density soils require 


\subsection{RADIONUCLIDES}

The ISV process has proven to be extremely effective in immobilizing radionuclides, including transuranic materials and fission products. Criticality limits have been established via conservative analyses at approximately $30 \mathrm{~kg}$ of plutonium per setting. Generally this means that soil concentrations at thousands of $\mathrm{nCi} / \mathrm{g}$ of TRU can be treated safely with ISV. When unusually high concentrations of cesium exist (i.e., multiple curies per setting), special measures must be taken to collect the small percentage ( $<3$ wt\%) of cesium that volatilizes and return it to the melt to avoid undesirable worker exposure. The ISV Integrated Program is currently developing and evaluating these techniques.

\subsection{HAZARDOUS INORGANIC CHEMICALS}

ISV is extremely effective in immobilizing heavy metals and other inorganic contaminants. The majority (70 to 99.99 wt\%) of heavy metals such as arsenic, lead, cadmium, barium, and chromium are retained and immobilized in the vitrified product. The remainder are collected by the off-gas system and either returned to the melt or disposed of separately. Nitrates are decomposed by the process, and mercury is removed and collected by the off-gas system for recovery or disposal.

\subsection{HAZARDOUS ORGANIC CHEMICALS}

ISV's high processing temperature destroys hazardous organic chemicals by pyrolysis. Organic concentrations of up to approximately 7 wt\% in the soil are processable with current ISV equipment. (The limit is based on the ability to handle the heat loadings from a given quantity of organics and is dependent on the distribution of organics in the soil and the Btu value associated with the particular organic species.) The small percentage of organic contaminants not destroyed by the process (between 0.01 and 1 wt\%) are 
removed from the soil by the process and collected by the off-gas treatment system. ISV should not, however, be currently applied to reactive or explosive materials, since very little theoretical or experimental work has been directed toward these types of materials. Although limited empirical data show that volatile organic compounds (VOCs), such as carbon tetrachloride and trichloroethylene, are effectively treated (Shade and Farnsworth 1990), the fate of this specific class of organics (i.e., those with boiling point temperatures of $100^{\circ} \mathrm{C}\left[212^{\circ} \mathrm{F}\right]$ or less) requires substantiation. Treatability studies can be used to resolve this issue on a site-specific basis. Meanwhile, the ISV Integrated Program is currently developing tools and collecting data to determine the fate of VOCs under a variety of processing conditions.

\subsection{SCRAP METALS}

With the recently developed electrode-feed system, which permits the electrodes to be inserted as the soil is melted downward, high scrap-metal concentrations are processable by ISV (e.g., 25 wt\% of metals has been demonstrated). When vitrifying soils containing buried metals, the metal melts and forms a molten pool at the bottom of the pool of molten soil. The presence of this molten metal phase can cause electrical short circuits between the electrodes. Electrode feeding allows the electrodes to be retracted a few centimeters above the molten metal to prevent such short circuits.

\subsection{DEBRIS AND RUBBLE}

Inclusions of high concentrations of concrete, rubble, rock, and other debris (up to 50 wt\%) are generally processable by ISV if all other operational constraints are met. Monolithic debris and structures configured so as to impede water vapor release from beneath the molten soil to the soil's surface should. be avoided unless sufficient analysis of the effects of the debris shows it to be acceptable.

\subsection{BURIED COMBUSTIBLES}

Although field data for buried combustible materials is limited, ISV has been shown to process more than 80 creosote timbers, each measuring $3.6 \mathrm{~m}$ long 
by $15 \mathrm{~cm}$ square, in a single large-scale setting. Based on the heat-removal capabilities of existing ISV equipment, combustible inclusions up to 7 wt\% are processable.

\subsection{SEALED CONTAINERS}

The ISV process is not currently applicable to sealed containers such as empty tanks, 55-gal (208.2-L) drums, or even 1-gal (2.8-L) paint cans because of the potential for expulsion of molten glass when these containers are breached during melting. Similar concerns exist for pocketed liquids. For many landfills, it is possible that the degree of corrosion would result in the degradation of sealed containers, which would largely eliminate the potential for transient gas release events. However, ISV holds great potential for reducing the occupational risk and costs of cleanup for these types of waste. The ISV Integrated Program and the Buried Waste Integrated Demonstration have made significant technological advancement for processing sealed containers in support of the INEL's Environmental Restoration Program.

\subsection{VOID VOLUMES}

Multiple small voids in the soil of up to $0.07 \mathrm{~m}^{3}\left(2.5 \mathrm{ft}^{3}\right)$ each can be processed by ISV. Until further research resolves questions regarding the effects of voids, larger single void volumes should be collapsed or filled to preclude the possibility of generating a large bubble ( $>1-m$ diameter) in the melt. Large bubbles can splatter unacceptable quantities of molten glass inside the hood when released at the molten surface. 


\subsection{REFERENCES}

Arrenholz, D. A. 1990. In Situ Vitrification Program Treatability Investigation Progress Report. EGG-WTD-9383, Revision 1, EG\&G-Idaho, Inc., Idaho Falls, Idaho.

Buelt, J. L., and L. E. Thompson. 1992. The In Situ Vitrification Integrated Program: Focusing an Innovative Solution on Environmental Restoration Needs. PNL-SA-20853, Pacific Northwest Laboratory, Richland, Washington.

Buelt, J. L., C. L. Timmerman, K. H. Oma, V. F. FitzPatrick, and J. G. Carter. 1987. In Situ Vitrification of Transuranic Waste: An Updated Systems Evaluation and Applications Assessment. PNL-4800 Supp 1. 1, Pacific Northwest Laboratory, Richland, Washington.

Callow, R. A., L. E. Thompson, J. R. Weidner, C. A. Loehr, B. P. McGrail, and S. O. Bates. 1991. In Situ Vitrification Application to Buried Waste: Final Report of Intermediate Field Test at Idaho National Engineering Laboratory. EGG-WTD-9807, EG\&G Idaho, Inc., Idaho Falls, Idaho.

Carter, J. G., S. O. Bates, and G. D. Maupin. 1987. In Situ Vitrification of Oak Ridge National Laboratory Soil and Limestone. PNL-6174, Pacific Northwest Laboratory, Richland, Washington.

Dev, H., G. C. Sresty, J. E. Bridges, and D. Downey. 1988. "Field Test of the Radio Frequency. In Situ Soil Decontamination Process." Proceedings of Superfund '88: HMCRI's 9th Annual Conference and Exhibition. November 29-30, 1988, Washington, D.C.

Dragun, J. 1990. "Geochemistry and Soil Chemistry Reactions Occurring During In Situ Vitrification." Journal of Hazardous Materials 26(1991):343-364.

Kuhn, W. L. 1992. Steady-State Analysis of the Fate of Volatile Contaminants During In Situ Vitrification. PNL-8059, Pacific Northwest Laboratory, Richland, Washington.

Liikala, S. C. 1991. Engineering-Scale Test Report for Applications of In Situ Vitrification Technology to Soils Contaminated with Polychlorinated Biphenyls at the Northwest Transformer Superfund Site. GSC 1006, Geosafe Corporation, Kirkland, Washington.

Mayberry, J. L., W. J. Quapp, F. Feizollahi, and J. C. Del Signore. 1991. Prel iminary Systems Design Study Assessment Report, Volumes I Through VII. EG\&G-WTD-9594, EG\&G-Idaho, Inc., Idaho Falls, Idaho.

McGrail, B. P., and S. O. Bates. 1991. Aqueous Dissolution of Laboratory and Field Samples from the In Situ Vitrification Process. PNL-SA-19786, Pacific Northwest Laboratory, Richland, Washington. 
Nickelson, D. F., J. Luey, and R. A. Callow. 1992. ISV Technology Development Plan for Buried Waste. EGG-WTD-10325, EG\&G-Idaho, Inc., Idaho Falls, Idaho.

Oma, K. H., M. A. H. Reimus, and C. L. Timmerman. 1989. Support for the In Situ Vitrification Treatability Study at the Idaho National Engineering Laboratory: FY 1988 Summary. PNL-6787, Pacific Northwest Laboratory, Richland, Washington.

Shade, J. W., and R. K. Farnsworth. 1990. Engineering-Scale Test 4: In Situ Vitrification of Toxic Metals and Volatile Organics Buried in INEL Soils. PNL-7611, Pacific Northwest Laboratory, Richland, Washington.

Thermal Process Evaluation for RWMC Wastes. 1991. EGG-WTD-9449, EG\&G Idaho, Inc., Idaho Falls, Idaho. (Cited in text as Thermal Process.)

Stoots, C. M., S. 0. Bates, R. A. Callow, K. A. Campbe11, R. K. Fransworth, G. K. Gratson, M. G. McKellar, D. F Nickelson, and C. E. Slater. 1991. Technical Issues Associated with In Situ Vitrification of the INEL Subsurface Disposal Area. Volume 1: A Systematic Approach for Identification, Prioritization, and Closure of Technical Issues. EGG-WTD-9985, EG\&G-Idaho, Inc., Idaho Falls, Idaho. 
$\bullet$

$\bullet$

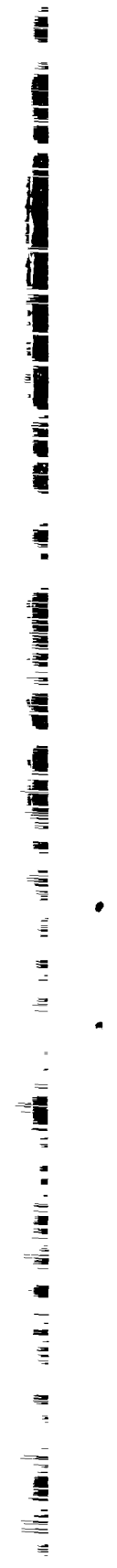

APPENDIX

KEY TECHNICAL ACCOMPLISHMENTS 
APPENDIX

\section{KEY TECHNICAL ACCOMPLISHMENTS}

\section{A.1 BACKGROUND}

The application of ISV to buried wastes is relatively new, and limited testing has been conducted since its development was initiated in 1988 . A total of three bench-, seven engineering-, and two intermediate-scale tests on simulated buried wastes have been conducted (Arrenholz 1990). These tests have gradually increased in the level of complexity and representativeness of actual waste types. The development of ISV for buried waste was initially limited to proof of principal tests of soil containing large quantities of buried metal since high concentration of metal was the primary challenge for the technology at that time. Resolution of this issue involved the development and implementation of electrode-feeding (moveable electrodes), which has been transferred to industry and is considered the reference operating concept for all applications because of its enormous cost benefits and operatior- 1 flexibility. As the development program evolved, additional technical sues were identified and a system was developed to identify and prioritize jes as well as outline strategies for resolution (Stoots et a1. 1991). The system developed to identify and prioritize issues was structured around the nine CERCLA criteria to help ensure that all aspects required for a decision from the remedial investigation/feasibility study (RI/FS) process were included in the development program. Progress towards resolution of technical issues has been achieved for many of the issues; however, additional work will be necessary to close others.

\section{A.2 IECHNICAL PROGRESS TO DATE}

Various tests, evaluations, and analyses have been conducted to help resolve the technical, regulatory, and programmatic issues that prevent deployment of the technology for buried-waste applications. This section describes the chronological progress relative to key tests and analyses. While many issues are not closed, results to date continue to support the viability of the technology for application to buried wastes. 


\section{A.2.1 Laboratory Testing}

During fiscal year (FY)-88 two engineering-scale tests were performed to determine the feasibility of vitrifying through localized concentrations of metals as high as 42 wt\% without incorporating special techniques to prevent electrical shorting between the electrodes (Oma et a1. 1989). Testing in FY-89 initially involved a series of eight crucible melts to determine if the addition of chemicals could decrease the quantity of metals reduced in the process. Although the chemical additions altered the viscosity and melting temperature of the soil mixture, they were ineffective in eliminating or reducing metal pooling. Subsequent to the crucible tests, three bench-scale tests were conducted in FY-89 to assess the treatability of heavy metals and asbestos, to evaluate the treatability of organic sludges and grease mixtures, and to evaluate the feasibility of inserting electrodes into molten soils. Results of these tests indicated that the asbestos was destroyed by the process; some heavy metals were volatilized and captured by the off-gas treatment system prior to encapsulation by the melt; and highly volatile halogenated hydrocarbons can be effectively processed without significant migration to surrounding soils.

A third engineering-scale test, conducted in FY-89, successfully demonstrated the feasibility of electrode-feeding on soils with high concentrations of metal (Arrenholz 1990). Electrical shorting between electrodes was alleviated with the moveable-electrode system, and the ability to accurately measure melt depth based on the depth of electrode insertion was confirmed. Additionally, the moveable-electrode process was shown to limit electrodecorrosion problems.

During FY-90, a series of four engineering-scale tests was conducted by both PNL and Geosafe Corporation for the Idaho National Engineering Laboratory (INEL). These four tests represented challenging configurations using simulated wastes representative of those expected to be encountered in the surface disposal area (SDA).

Engineering-Scale Test 4: This test involved a mixture of organic materials and heavy metals and was designed to determine the destruction and removal efficiencies of hazardous volatile organic materials and heavy metals, 
to determine the leach rate of heavy metals from the resulting product, to determine the volume reduction possible by the ISV process, and to determine the effectiveness of electrode coatings in minimizing electrode oxidation (Shade and Farnsworth 1990). The resulting glass product passed the Toxicity Characteristic Leach Procedure (TCLP) test. No significant transport of contaminants into surrounding soils was observed, and the collective mass of surrounding soil was designated as unregulated; only a single soil sample directly adjacent to the melt contained concentrations of cadmium that exceeded TCLP 1imits (1.9-ppm cadmium versus a TCLP 1imit of $1 \mathrm{ppm})$. The destruction/removal efficiency was greater than $99.9 \%$ for two volatile organic compounds, trichloroethylene and tetrachioroethylene. The metal phase resulting from the test passed leach-testing criteria for all metals except for lead. Additionally, the test demonstrated the ability of the process to melt into and solidiy fuse to an underlying block of basalt. Coatings designed to limit oxidation of the graphite electrodes were effective but not necessary; in addition, the coating resulted in one electrode sticking to the frozen layer of glass covering the surface of the melt.

Engineering-Scale Test 5: This test involved 200 small sealed metal canisters in a single horizontal layer. ${ }^{\text {(a) }}$ The canisters contained a mixture of sludges representative of the wide ranging inventory of wastes in the SDA. The purpose of the test was primarily to determine the effect of a close-packed layer of sealed cans on ISV processing performance, including the nature of gas releases from the sealed cans when encountered by the melt. other objectives were to evaluate

- the potential for volatile metal and volatile organic compounds to migrate to clean soils

- the fate of semi-volatile and volatile organic contaminants, including carbon tetrachloride, trichloroethane, trichloroethylene, tetrachloroethylene, and mercury

- glass quality and surrounding soils relative to TCLP standards

(a) Bergsman, T. M., and J. W. Shade. Draft 1991. Fifth Engineering-Scale In Situ Vitrification Test of Simulated INEL Buried Wastes. Pacific Northwest Laboratory, Richland, Washington. 
- and the potential for entrainment of lanthanide tracers to the offgas hood during canister depressurizations.

Test 5 was a worst-case representation because the high-integrity stee 1 canisters that were used did not simulate the low-integrity waste package that would be expected within the SDA after 20+ years of burial. Additionally, the test was designed to be non-conservative in that the wide range of waste sludges expected in the SDA were combined to form complex mixtures containing both organics and oxidizers. During the test, approximately $25 \%$ of the canisters ruptured, with releases significant enough to pressurize the containment vesse1. Data from the test indicate that the rupturing was caused by energetic reactions between the mixture of nitrates and organics within the individual cans. It is believed that some of the cans actually exploded, and although the containment vessel momentarily pressurized, no equipment was damaged. Since these waste types are normally packaged separately and would not exist in high-integrity containers, this type of energetic reaction would not be expected to occur when vitrifying the SDA wastes. In one soil sampie, mercury contamination was found on the opposite side of the melt from where it was initially located. It is suspected that this transport was the result of a rapid canister depressurization.

A mathematical relationship of the canister depressurization rate relative to the total amount of gas released to the containment system was established; this relationship may be useful for large-scale applications involving 55-gal (208.2-L) drums, provided the scaling relationships from an engineering - to large-scale environment are determined. The relationship can be summarily described relative to mass-balance relationships and involves the integration of the flow rate through the off-gas system minus the inflow to the containment system as a function of time.

The vitrified product passed TCLP leach-testing criteria. A11 surrounding soil samples passed TCLP criteria, except for a single soil sample contaminated with mercury below the canister layer at the $100^{\circ} \mathrm{C}\left(212^{\circ} \mathrm{F}\right)$ isotherm. It is suspected that this small quantity of mercury was transported to this location during an energetic canister depressurization. The lanthanide tracers were used to simulate plutonium. 
Essentially all of the tracers were incorporated into the melt; these tracers were not transported to the surrounding soil, and only a small amount was transported to the off-gas containment system, probably during sudden gas-release events. This represents very positive results for such adverse buried-waste processing conditions.

Engineering-Scale Tests 6 and 7: These two tests, performed by Geosafe Corporation for the INEL, involved the same sludge mixtures and cans as those used in Test 5 (Arrenholz 1990). The cans were arranged in a random disposal array. Test 6 objectives were primarily oriented towards obtaining data on the canister burst pressure and depressurization rates and corresponding effects in the containment vessel, including off-gas composition. Test 7 involved the same sludge mixtures and the same type of cans as Tests 5 and 6 and was designed to determine the can burst pressures, depressurization rates, and resulting effects in the containment vessel as a function of canister burial depth. It was suspected that the efficiency of treatment relative to destruction and removal efficiency increased as a function of burial depth. Additionally, empirical observations tended to show that the pressure and temperature spikes in the containment vessel were lessened as a function of the burial depth of the waste container. Data collection for Test 7 was similar to that for Test 6 . Results for these tests are similar to Engineering-Scale Test 5 conducted by PNL; however, the magnitude of pressures achieved in the sealed cans and the corresponding responses in the containment hood were typically less than those observed in Test 5 . This difference is suspected to be due to a variation in the can-sealing procedure.

\section{A.2.2 Field Tests}

Two pilot-scale tests on simulated buried waste sites were conducted during June and July of 1990 (Callow et al. 1991). Both tests were designed to test the feasibility of the process on representative waste configurations expected in the SDA. Test 1 involved a random dump arrangement of cans and boxes. The cans were approximately $2.5 \mathrm{gal}(9.5 \mathrm{~L})$ in size and were scaled representations of 55-gal (208.2-L) drums to match the reduced size of the test equipment. The cans contained a variety of non-hazardous materials simulating the typical waste forms expected in the SDA. This included cans of wet sludge, paper, rags, wood, concrete, metal, and glass. Test 1 also

$$
\text { A. } 5
$$


involved several wood pallets and a varfety of cardboard boxes containing concrete, glass, and metal. The wastes were randomly dumped in the test pit at depths of $61 \mathrm{~cm}(2 \mathrm{ft})$ to $2.45 \mathrm{~m}(8 \mathrm{ft})$.

Test Pit 2 involved stacked 3-deep layers of 2.5-gal $(9.2-L)$ cans placed directly above a configuration of stacked boxes (same contents as Pit 1). Figure A.1 shows the can layer of Test Pit 2 during construction. A soil overburden of $1.22 \mathrm{~m}(4 \mathrm{ft})$ was provided for Test Pit 2, with the bottom of the waste at a depth of $3.05 \mathrm{~m}(10 \mathrm{ft})$. Randomly selected cans in both tests contained rare-earth tracers to assess the potential for radionuclide transport. A single, instrumented, sealed can containing approximately $1.8 \mathrm{~kg}$ (4 lbs) of paper was buried at a depth of $61 \mathrm{~cm}(2 \mathrm{ft})$ to provide data on can pressures and temperatures. The objectives of Tests 1 and 2 were to

- verify the operational suitability of the electrode-feed system for the first time during a field-scale test

- verify acceptable vitrification in a region containing buried waste similar to that expected in the SDA

- verify acceptable vitrification of a representative buried-waste composition layer containing a minimal amount of soil

- verify acceptable vitrification of a buried-waste layer with high metal content, approximately 11 wt\%

- assess the potential for radionuclide transport during vitrification of buried wastes by using non-radioactive tracers (dysprosium, terbium, and ytterbium oxides)

- obtain engineering and scientific data necessary to assess the engineering capability of the ISV system, the safety of the process streams, and the suitability of the process as a remedial method for appiication to INEL buried wastes.

Test 1 operations were successful based on achieving a vitrification depth of $2.45 \mathrm{~m}(8 \mathrm{ft}$ ) in slightly more than 18 hours (target depth was $1.83 \mathrm{~m}$ [6 ft]). The process resulted in very dynamic transient events in the containment hood with the processing of each waste package. Significant temperature and pressure spikes were observed in the hood throughout the test and appeared to be associated with each encounter of a buried box or sealed can. Figure A.2 is a plot of the hood vacuum and plenum temperature for Test 1 and illustrates the dynamic nature of the test. However, the transient 
and escaped from the cans into the surrounding soils well aneau ur ure approaching melt front. Combined with the additional $2 \mathrm{ft}$ of overburden, the lack of water vapor in the cans is suspected to be largely responsible for the absence of the dynamic transient events that were observed in Test 1 . Volume reduction for this configuration was approximately $60 \%$.

All waste forms encountered by the melt were completely processed. The product from both tests generally consisted of a black glassy material containing variable amounts of crystalline materials and bubbles. Some devitrification occurred in the inner portions of the larger monolith from Test 2, producing a feather-like crystalline phase called augite. Augite is a naturally occurring pyroxene found in volcanic rocks that have compositions and cooling histories similar to the ISV product. Post-test excavation revealed evidence of extremely steep thermal gradients around the melt. Paper that appeared to be unaltered by heat was found in many instances within a few inches from the melt front, which indicated that the probability of an underground fire being initiated by an ISV melt is low, primarily due to the lack of sufficient quantities of subsurface oxygen. (a)

Product evaluation testing included forward rate dissolution testing, both Materials Characterization Center-1 (MCC-1) and TCLP. The waste form passed TCLP criteria, and results from MCC -1 testing revealed that the durability of the waste form is comparable to naturally occurring obsidian and granite, and it is 4 to 10 times more durable than typical high-level borosilicate nuclear waste glasses. Intrinsic rate-constant measurements showed the dissolution rates of the product to be 10 to 100 times smaller than those measured for a borosilicate high-level waste glass. Additionally, the devitrified samples (crystalline phases) exhibited greater durability than the amorphous samples. Additional evaluations showed that, under conditions of

(a) Note that the presence of oxidizers combined with organic materials could potentially sustain underground combustion, a possibility that has not yet been evaluated. 
groundwater flowing through cracks, several redox-sensitive elements, such as selenium and plutonium, would likely be sequestered in an alteration layer on the glass surface, resulting in a smaller predicted release rate than that calculated from the matrix-dissolution rate alone.

Compositional analyses of the product, the surrounding soils, and the off-gas treatment system indicated that the majority (>90\%) of the rare-earth tracers were retained in the vitrified product while no contaminant migration was observed in the surrounding soils as expected. However, additional fieldscale work would more accurately quantify the retention of these types of materials during processing of buried wastes.

\section{A.3 IECHNICAL ANALYTICAL STUDIES}

\section{A.3.1 Control of Transient Gas Surges}

As a result of the FY-90 INEL field tests, the primary technical issue addressed by PNL in FY-91 involved containment of transient gas surges. A study was initiated to evaluate means of eliminating or reducing the magnitude of transient gas releases. Two primary methods were identified, one involving the removal of energy from the hood system, the second involving the rapid removal of gas from the hood during transierit releases. A multi-client engineering-scale test conducted at PNL obtained test data for a proof-ofprinciple energy-removal concept to enhance the ability to contain the transient gas surges. Water was sprayed into the plenum space of the containment hood when the initial phases of a transient gas surge was detected. (Refer a) so to Section 7.2 of this technology status report.) Calculations indicate that the significant heat of vaporization of water will result in a significant and rapid reduction in the average temperature in the plenum, resulting in a net decrease in pressure. The net increase in the volume of gas due to the addition of water is dramatically off-set by the overall net temperature reduction of the system. Calculations indicate that a system injecting as little as one pound of water would counteract the transient surges experienced during Test 1 of the FY-90 field tests. The testing was successful in that data indicated that a rapid and significant increase in hood vacuum could be achieved. During FY-91, the design and fabrication of a pilot-scale waterspray system was completed. The second concept identified to control

A. 10 
transient gas surges was evaluated in FY-91 and resulted in the design and fabrication of a prototype blower system for the pilot-scale system. This blower system provided a more aggressive gas-removal capability from the containment hood during transient surges.

\section{A.3.2 Criticality Analyses}

Criticality avoidance was identified early in the program as a key technical issue and was initially investigated in $1990 .{ }^{\text {(a) }}$ The potential for accumulation of a critical mass within the melt during processing or after the molten soil cools was the primary concern identified, particularly for plutonium, as this is the predominant radionuclide in the SDA. Proposed concentration mechanisms evaluated included the following:

- the exceeding of solubility limits of various fissionable nuclides, which could allow these materials to settle out of the melt and form a concentrated mass

- some undefined concentrating mechanism whereby the fissionable nuclides are concentrated either ahead of the advancing melt front or are not fully dissolved in the melt

- the reduction of radionuclides from oxide form to their metallic state, forming a molten pool of the radionuclide species at the base of the molten pool.

The conclusions of this evaluation were that the INEL soils contained sufficient concentrations of boron to help preclude the formation of a critical mass. Specifically, the minimum critical spherical mass was calculated to be $3-\mathrm{kg}$ (6.6-lbs) plutonium, and the minimum critical areal concentration is approximately $4.3 \mathrm{~kg} / \mathrm{m}^{2}\left(88 \mathrm{lbs} / \mathrm{ft}^{2}\right)$ of INEL soil configurations. For comparative purposes, the concentrations for Hanford soil were calculated to be $1.7-\mathrm{kg}(3.74-1 \mathrm{bs})$ plutonium for the minimum critical spherical mass and approximately $2.9 \mathrm{~kg} / \mathrm{m}^{2}\left(0.59 \mathrm{lbs} / \mathrm{ft}^{2}\right)$ for the minimum critical areal concentration.

In cases where iron is present with plutonium metal, as would be expected in an ISV melt involving a high concentration of buried metal, the

(a) Libby, R. A. et al. 1990. ISV Criticality Safety Analysis of INEL Soil. Informal Report, Pacific Northwest Laboratory, Richland, Washington. 
iron will act as a diluent and increase the minimum critical mass (providing a higher degree of safety). It should be noted that additional mechanisms and other radionuclides were not evaluated in the study and may require further analyses. Mechanisms not analyzed include the following possibilities:

- There may be a concentrating mechanism inside the containers before the containers are melted, and before the waste mixture is consumed into the molten soil.

- Multiple inclusions representing a substantial quantity of plutonium metal within an individual process setting could sink to the bottom of the melt before dissolving, forming a critical mass.

- Soil and wastes may be dried as the melt front approaches, effectively removing the moderating forces of water.

- Fissionable materials could accumulate in the off-gas treatment system. Under certain circumstances over extended periods of operation, plutonium will be entrained with gas releases from the melt and will accumulate in the off-gas treatment system.

Normal1y, extremely high retentions of plutonium in the melt system would be expected; however, dynamic gas releases from sealed containers or pyrolysis/combustion activities could result in increased transport of plutonium to the off-gas treatment system.

\section{A.3.3 Modeling Efforts - Summary}

The modeling efforts of INEL and PNL described in the following two sections have produced limited outputs, which is generally consistent with the level of maturity of these models. In the following sections, there is no attempt to pass judgement on the merits of any individual code or set of codes. Each has advantages and disadvantages. Some code development/ application efforts described have received little attention, while others have received considerable attention and have produced results that have significantly improved the understanding of the process. One difficulty is that much of the modeling suffers from a lack of data to validate assumptions and outputs, particular since few large-scale tests have been conducted. In general, where the model development has been closely coupled with experimental work to help resolve issues, the modeling efforts have produced more usefur and timely outputs. Modeling is often essential in developing an understanding of the process and, hence, a predictive capability; however, it 
must be selectively applied and closely coupled with the efforts of the experimentalists.

\section{A.3.4 INEL Computer-Modeling Efforts ${ }^{(a)}$}

of the three laboratories involved in ISV model development, INEL has pursued the most aggressive and wide-ranging campaign to develop this capability. This pursuit began in FY-90 and has led to a suite of computational tools that are intended for use in ISV safety assessments of the candidate INEL waste sites. The codes developed are described in the context of the issue they are intended to address. In general, however, the INEL approach has been to produce a set of software tools designed to model a unique part of the total ISV process. In this way, the relevant physical phenomena are effectively uncoupled. Any coupling between physical phenomena is provided externally by the analyst. Development plans include the coupling of these computer codes. Current code-development efforts are focused on VULCAN and TOUGH, described below.

Melt Depth - The backbone of the suite of INEL ISV computational tools for assessing melt depth and progression is VULCAN. This code is derived from the widely available TOPAZ-30 thermal-analysis program. VULCAN is a finiteelement program used to compute the three-dimensional heat transport and temperature distribution in the ISV heat-affected zone. VULCAN is primarily a heat-conduction code and does not model convention.

A11 thermophysical properties of the waste site (e.g., thermal conductivity and specific heat) can be input as functions of temperature. Site heterogeneities can also be modeled by assigning different material properties to a group of elements (or cells) in the computational domain. These heterogeneities cannot explicitly dissolve into the melt, however. Therefore, the interface between different materials remains distinct throughout the analysis.

(a) A concise description of ISV modeling efforts is described in the draft, ISV Modeling Coordination Report (Lowery 1991). 
Key characteristics of VULCAN include the following:

- VULCAN models the electric field based on electrode spacing, size, and power input.

- VULCAN models a moving melt front because it models the physics of the melting media, models subsidence via the conservation of mass, and also tracks moving electrodes.

- VULCAN has had some validation using data from the 1984 PNL PilotScale Radioactive Test reported in PNL-4800 (Buelt et al. 1987).

- VULCAN is a fulty implicit code.

The ISV process has been modeled at INEL using the thermal/fluid commercial code FIDAP (Engleman 1991; Hawkes 1991). FIDAP is a well established and validated commercial code that models the fully coupled Navier Stokes and energy equations. It models melting media and therefore models a moving melt front. It is a fully implicit finite element code. It models the electric field and convection within the melt. It models flow through saturated porous media and non-Newtonian fluids. It does not, however, model subsidence.

The code MAGMA has been developed at INEL to model three-dimensional, incompressible, viscous flow and heat transfer. A melting model was developed within the code to study the melt front progression and latent heat effects. An indirect addressing scheme used in the numerical solution of the momentum equation avoids unnecessary calculations in cells devoid of liquid. The code is a semi-implicit finite difference code. MAGMA does not model the electric fields equations, but uses a variable heat source to account for the Joule heating.

Contaminant Transport - INEL is investigating the use of the TOUGH code and its extensions (e.g., STMVOC) to assess the effect of steam/water migration on the migration of contaminants around the melt. Both TOUGH and STMVOC were written by members of the Earth Sciences Division at Lawrence Berkeley Laboratory. The codes allow a three-dimensional representation of the subsurface region. The transport of water, steam, and, in the case of STMVOC, an additional volatile species in porous and/or fractured media can be simulated. In their present state, both codes will require significant modifications and enhancements to allow more complete modeling of the steam/water 
migration phenomena around an ISV melt. TOUGH is widely available and has been used to develop an understanding of the vapor release issue. STMVOC, on the other hand, is relatively new and, consequently, is available to outside users on a very limited basis only.

Off-Gas Releases from the Melt - Bubble formation, growth, and migration through the melt can provide significant loads to the off-gas plenum as well as potentially disruptive loads to the melt itself. With this in mind, INEL has attempted to formulate a model to address these phenomena. The product of this development is a code called OGRE. OGRE models the one-dimensional transport of condensable and non-condensable gases through the melt. Bubbles are assumed to be introduced to the melt either at the melt "front" or as point sources within the melt (as might be representative of the rupture of a waste container). Important considerations relating to initial bubble size, loading, and composition at the melt interface are required in the input to OGRE. Obtaining appropriate data to properly describe these input data is a major task in and of itself, and supporting experimental data are not currently available. As a consequence of the lack of this information, OGRE has not received much application to ISV scenarios.

Process Chemistry - As part of the ISV process, organic and inorganic contaminants embedded in the soil are destroyed by either combustion or pyrolysis. The products of these reactions could conceivably provide loads to the off-gas plenum. INEL plans to perform these assessments with the APOLLO code. This code allows both equilibrium and reaction kinetics chemistry to be performed for a user-defined mix of reactants and plausible reactions.

Limited code verification has been performed. Again, however, validation of APOLLO will likely prove to be a significant undertaking.

Mass and energy releases to the off-gas hood can provide significant thermal and pressure loads, which must be accounted for in the design of the hood. INEL has attempted to assess these loads with the aid of two computational tools, VESTA and COYOTE. Both codes simulate the transient behavior of compressible, reacting flows using a two-dimensional, finite-difference representation of the governing conservation equations. VESTA is intended to track the long-term dynamics of a flowing, reacting mixture of gases. COYOTE, on the other hand, is designed to simulate those reactions that occur on a

\section{A. 15}


relatively short time scale. Inputs form codes previously described, such as heat leads and bubble releases, which will provide part of the input loadings or source terms to either COYOTE or VESTA. Both codes have gone through a verification phase and a limited validation phase. They have not, however, received extensive validation.

\section{A.5 PNL COMPUTER MODELING EFFORTS}

As the inventors of the ISV process, PNL has long had an interest in predicting the evolution of melt growth and contaminant fate and migration. As a consequence, significant efforts have been directed over the years toward developing a computational model that would be useful in predicting melt trends in the ISV process. The approaches taken have covered the gamut in level of sophistication, from personal computer models to full threedimensional solutions of the governing conservation equations.

\section{A.5.1 Melt Depth}

The computational tool with the longest track record in predicting melt depth and progression is the PNL personal computer model. This model has been under development almost since the inception of ISV and is relatively simple because it is based on experimental data, rather than first principles. It was developed to provide an easy-to-use tool for the ISV engineer to use in estimating the ultimate melt depth and aspect ratio; the time duration required to achieve a desired depth; and the electrical voltage, current, and power consumption requirements within the constraints of its empirical base (Koegler and Kindle 1991). The PC model is not intended to function as a numerical tool to help understand the physics of the ISV process; it is merely a simple engineering tool to provide a qualitative prediction of key process results within the boundaries of limited empirical data. The PNL personal computer model combines the storehouse of ISV user experience gained at PNL over the years, together with global energy conservation, to yield a method for predicting the downward and lateral growth of the melt as a function of time. Input parameters include system configuration (e.g., electrode size and separation) and thermophysical soil properties. Correlations are included in the code to account for soil sloughing and subsidence. Correlations are also invoked to relate the lateral-to-downward growth rate of the melt based on the 
relative rate of heat transfer out the sides and bottom of the melt. For the most part, these correlations reflect the wealth of user experience gained from experiments performed by PNL staff. More recently, however, they have been modified to incorporate some of the heat-flux distribution results obtained from TEMPEST ISV simulations. Six-phase, six-electrode configurations, as well as the standard four-electrode Scott-Tee configurations, can be modeled with this code.

The PNL personal computer model has had noteworthy success at predicting the melt's progress, voltage, current requirements, and power consumption for a basic class of ISV sites. It has limitations, however. It is restricted to "typical" ISV melts. Because the code is quasi one-dimensional and assumes uniform soil properties, it is not designed to provide insight into the dynamics of the melt process in a heterogeneous environment. Moreover, it is difficult to assess the impact of many system-design modifications (e.g. "hot tip" electrodes and three-phase, three-electrode systems) and other "offnormal" site characteristics without significant re-tuning of the model.

In part as a consequence of these limitations, PNL has, since 1988, pursued the application and development of the TEMPEST computer code for use in the prediction of ISV melt growth, and progression. TEMPEST is a finitedifference computer code that solves the full three-dimensional system of mass, momentum, energy, and species-conservation equations (Lessor et a1. 1990). Moreover, solution of the constituent conservation equations can, if desired, be de-coupled from one another. This is not routinely done, however, as it is felt that the thermal and hydrodynamic processes are sufficiently non-linear to warrant close coupling in the solution of their respective conservation equations. As with most codes of this form, simpler one- and two-dimensional simulations can be performed when warranted with merely a change in the input structure provided to describe the geometry of the problem to the code. In TEMPEST all material properties can be functions of temperature.

For ISV, TEMPEST has been modified to allow solutions of the threedimensional electric charge conservation equation. Additionally, heterogeneities can be modeled by specifying different material properties for subsets of the computational domain. By combining the species-transport

$$
\text { A. } 17
$$


capability with the ability to weight the local transport properties of the material based on the relative volume concentrations of these species, assimilation of molten heterogeneities into the melt can be modeled. Phase change and latent heats can be accounted for by altering the temperaturedependent specific heat curve in the vicinity of the material-transition temperature.

The TEMPEST model, as described above, has been applied to simulate a number of ISV scenarios. The temperature, flow, and heat-transfer distributions have been used to gain additional insight into the melt progression process. Phenomena such as thermal and joule heat stratification have been studied.

A capability has been added to track a moving melt "front" and electrode-feed system. In addition, modifications have been incorporated to account for soil densification during melting as a means to account for subsidence. Current simulations are exercising these enhancements to gain further insight into the dynamics of the ISV melt process.

\section{A.5.3 Contaminant Fate and Migration}

This issue has received significant attention in the last two years. The initial approach to analyzing this situation has concentrated on the steam-stripping phenomena present in the vicinity of the melt "front" (Kuhn 1992). A quasi two-dimensional analysis of the dynamics of steam, water, and contaminant migration in the region just outboard of the moving ISV melt "front" is described by Kuhn. This model represents a semi-analytic solution to the radial component of the mass-and-energy conservation equations for flow of constituent species in a spherically symmetric, semi-infinite porous media. Boundary conditions that effectively allow steam to escape laterally from the computational domain are applied in the analysis. Hence, the quasi twodimensional nature of the technique. The effects of permeability, desaturation, thermophoresis, and capillary and pressure forces are accounted for in this approach. Results indicate the dominant factor influencing whether a given volatile species will be effectively treated by the ISV process is the rate of sorption/desorption of the volatile in the soil. 
As a parallel effort, the TOUGH computer code is being adapted and applied to study the behavior of steam-and-water migration around an ISV melt. These studies make use of the full two- and three-dimensional capability of the code to assess the potential toward pressure buildup below, due to variations in soil conditions or the presence of structures that may restrict the normal flow of gasses through the soil column surrounding the melt. Studies conducted to date indicate that processing of contaminated soils in sandy soils does not result in sufficient gas-flow restrictions through the soil to cause sufficient pressure beneath a melt to be of concern. (a)

\section{REFERENCES}

Arrenholz, D. A. 1990. In Situ Vitrification Program Treatability Investigation Progress Report. EGG-WTD-9383, Revision 1, EG\&G-Idaho, Inc., Idaho Falls, Idaho.

Callow, R. A., L. E. Thompson, J. R. Weidner, C. A. Loehr, B. P. McGrail, and S. 0. Bates. 1991. In Sity Vitrification Application to Buried Waste: Final Report of Intermediate Field Test at Idaho National Engineering Laboratory. EGG-WTD-9807, EG\&G Idaho, Inc., Idaho Falls, Idaho.

Engleman, M. S. 1991. "FIDAP Theoretical Manual, "Version 6.0. Fluid Dynamics International, Evanston, Illinois.

Hawkes, G. L. 1991. "Influence of Natural Convection on Melt Shape During In Situ Vitrification." In Heat Transfer in Geophysical Media, eds. R. J. Couvillion, et al. HTD-Vol. 172, American Society of Mechanical Engineers, New York.

Kuhn, W. L. 1992. Steady-State Analys is of the Fate of Volatile Contaminants During In Situ Vitrification. PNL-8059, Pacific Northwest Laboratory, Richland, Washington.

Koegler, S. S., and C. H. Kindle. 1991. "Modeling of the In Situ Vitrification Process." Ceramic Bulletin 70(5):832-835.

Lessor, D. L., L. L. Eyler, and P. S. Lowery. 1991. "Joule Heat Calculations for Simulations of Multielectrode Glass Melters and In Situ Vitrification Systems." Glastechnische Berichte: International Journal of Glass Science and Technology 64(4):95-105.

(a) Roberts, J. S., S. L. Woosley, D. L. Lessor, and D. Strachan. Draft 1992. Investigation of the Potential for Transient Vapor Release Events During In Situ Vitrification Based on Thermal-Hydraulic Modeling. Pacific Northwest Laboratory, Richland, Washington. 
Oma, K. H., M. A. H. Reimus, and C. L. Timmerman. 1989. Support for the In Situ Vitrification Treatability Study at the Idaho National Engineering Laboratory: FY 1988 Summary. PNL-6787, Pacific Northwest Laboratory, Richland, Washington.

Stoots, C. M., S. O. Bates, R. A. Callow, K. A. Campbell, R. K. Fransworth, G. K. Gratson, M. G. McKellar, D. F. Nickelson, and C. E. Slater. 1991. Technical Issues Associated with In Situ Vitrification of the INEL Subsurface Disposal Area. Volume 1: A Systematic Approach for Identification. Prioritization, and Closure of Technical Issues. EGG-WTD-9985, EG\&G-Idaho, Inc., Idaho Falls, Idaho. 
No. of

Coptes

\section{OFFSITE}

12 DOE/Office of Scientific and Technical Information

21 DOE Office of Environmental Restoration and Waste Management

Trevion II Building 12800 Middlebrook Road Germantown, MD 20874

ATTN: W. W. Alexander

T. D. Anderson

J. E. Baublitz

D. L. Biancasino

J. 0. Boda

J: A. Coleman

S. P. Cowan

J. J. Fiore

C. W. Frank

K. 0. Hain

J. M. Lankford

J. C. Lehr

S. C. Lein

J. E. Lyt7e

S. A. Mann

S. M. Prestwich

M. W. Shupe

C. H. Sink

L. H. Taylor

H. F. Walter

R. P. Whitfield

2 DOE Albuquerque Operations Office

P.0. Box 5400

Aibuquerque, NM 87115

ATTN: P. A. Saxman

D. H. Bandy

W. Holman

DOE San Francisco Field Office

1333 Broadway

Oakland, CA 94612
No. of

Coptes

J. Haugen

DOE Chicago Field Office

9800 South Cass Avenue

Argonne, IL 60439

J. Hall

DOE Nevada Field Office

P.0. Box 98518

Las Vegas, NV 89193-8518

R. Tyler

DOE Rocky Flats Office

DOE Building 116

Golden, CO 80402-0928

S. Ketola

DOE West Valley Project

P.O. Box 191

West Valley, NY 14171

W. Fitch

DOE Idaho Operations Office

785 DOE P1ace

Idaho Falls, ID 83402

M. O'Rear

DOE Savannah River Operations Office

P.0. Box A

Aiken, SC 29801

4 DOE Oak Ridge Office

P.0. Box 2001

Oak Ridge, TN 37831

ATTN: J. Moore (2)

J. Sweeney (2)

3 Battelle Memorial Institute

505 King Avenue

Columbus, $\mathrm{OH} 43201$

ATTN: W. A. Carbeiner

R. A. Nathan

Technical Library

Distr.1 
vesse L. in, ..

Lawrence Livermore National

Laboratory

7000 East Avenue

Livermore, CA 94550

M.A.H. Reimus

Los Alamos National Laboratory P.0. Box 1663

Los Alamos, NM 87545

J. Koger

Martin Marietta Energy Systems

P.0. Box 2009

Oak Ridge, TN 37831-8097

P. T. Owen

Mart in Marietta Energy Systems P.0. Box 2003

Oak Ridge, TN 37831-7256

8 Oak Ridge National Laboratory P.0. BoX $Y$

Oak Ridge, TN 37830

ATTN: G. K. Jacobs (4)

M. Naney (2)

B. P. Spalding (2)

K. Nuhfer

Westinghouse Materials Co. of Ohio

P.0. Box 398704

Cincinnati, $\mathrm{OH}$ 45239-8704

5 Sandia Laboratories

P.0. Box 5800

Aibuquerque, NM 87185

ATTN: D. Berry

R. Knowiton

J. Phelan

L. D. Tyler

Technical Library
4 tliakl Iaano

P.0. Box 1625

Idaho Fal1s, ID 83415

ATTN: S. K. Merril1

D. F. Nickel son

R. R. Stiger

S. Stiger

L. Rogers

EG\&G Energy Measurements, Inc.

P.0. Box 1912, MS RSL-11

Las Vegas, NV 89125

B. Haas

Ames Laboratory

7 Spedding Hall

Iowa State University

Ames, IA 50011

6 Westinghouse Savannah River

Company

P.0. Box 616

Aiken, SC 29801

ATTN: J. S. Haselow

C. M. Jantzen

M. J. Plodinec

J. F. Sproull

J. L. Steele

T. Waiton

J. M. Pope

West Valley Nuclear

Services Co.

P.0. Box 191

West Valley, NY 14171

3 Geosafe Corporation

2950 George Washington Way \#A

Richl and, WA 99352-1615

ATTN: C. L. Timmerman (2)

J. E. Hanson 
E. A. Bracken, A6-95

K. W. Bracken, A5-22

R. P. Carter, A5-21

P. K. Clark, $A 6-80$

P. F. Dunigan, A6-95

J. K. Erickson, A5-19

R. D. Freeburg, A5-19

M. J. Furman, $A 6-80$

R. E. Gerton, A6-80

J. D. Goodenough, A5-22

J. M. Hennig, A5-21

R. D. Izatt, $A 6-95$

J. J. Sutey, A5-90

13 Westinghouse Hanford Company

W. C. Alaconis, L4-92

H. Babad, B3-68

J. D. Berger, LO-18

J. W. Cammann, H4-54

K. R. Fecht, H4-56

R. E. Lerch, B2-35

H. E. McGuire, B2-35

J. W. Shade, R4-03

D. A. Turner, R1-10

D. D. Wodrich, R1-48

R. D. Wojtasek, B2-15

B. A. Wolfe, L5-61

R. L. Gilchrist, L5-63
H. C. Burkholder, P7-41

c. C. Chapman, P7-41

T. T. Claudson, K1-66

D. J. Hanley, K3-53

C. H. Kindle, P7-41

W. L. Kuhn, P8-38

J. T. Jeffs, P7-43

P. A. Lowery, K7-15

J. Luey, P7-34 (5)

J. L. MCET roy, P7-46

M. E. Peterson, P7-41

T. D. Powe11, P7-34

S. C. Slate, K1-25

S. L. Stein, K1-25

L. E. Thompson, P7-34 (5)

J. S. Tixier, P7-34

c. L. Widrig, K1-25

S. L. Woosley, P7-34

Publishing Coordination

Technical Report Files (5)

Distr.3 

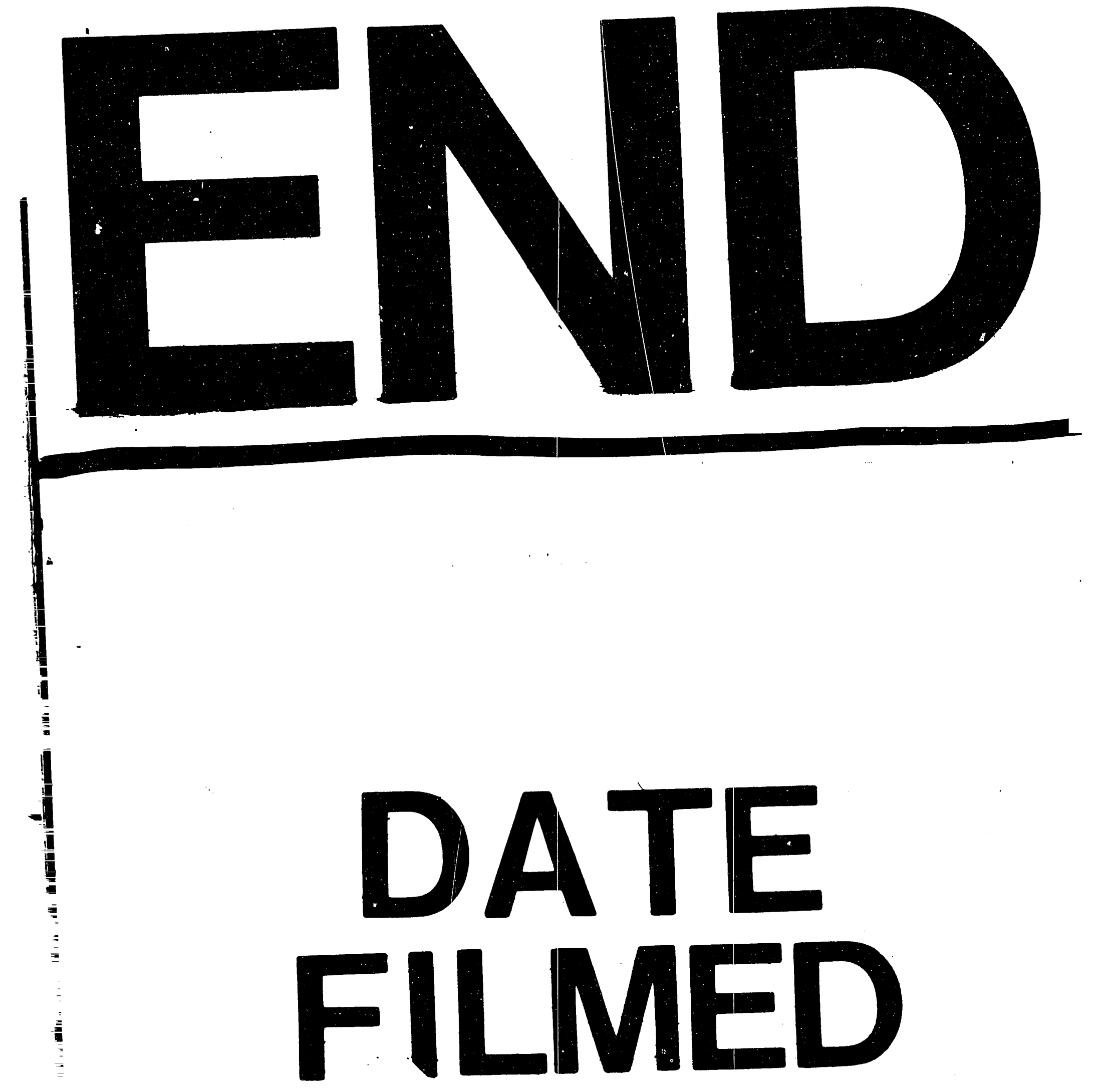

$10 / 29 / 92$ 


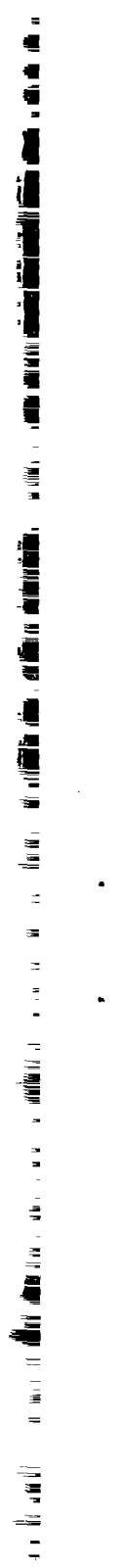

